Supporting Information for

\title{
Mechanistic Insights into Catalytic Oxidations of Organic Compounds by Ruthenium(IV)-Oxo Complexes with Pyridylamine Ligands
}

Shingo Ohzu, ${ }^{a}$ Tomoya Ishizuka, ${ }^{a}$ Yuichirou Hirai, ${ }^{b}$ Hua Jiang, ${ }^{a}$ Miyuki Sakaguchi, ${ }^{c}$ Takashi Ogura ${ }^{c}$ Shunichi Fukuzumi, ${ }^{*},{ }^{b} d$ and Takahiko Kojima*a

${ }^{a}$ Department of Chemistry, Graduate School of Pure and Applied Sciences, University of Tsukuba, 1-1-1 Tennoudai, Tsukuba, Ibaraki 305-8571, Japan

${ }^{b}$ Department of Material and Life Science, Graduate School of Engineering, Osaka University, and ALCA, JST, 2-1 Yamada-oka, Suita, Osaka 565-0871, Japan and ALCA, JST

${ }^{c}$ Graduate School of Life Science, University of Hyogo, Kouto, Hyogo 678-1297, Japan

${ }^{d}$ Department of Bioinsipired Science (WCU project), Ewha Womans University, Seoul, 120-750, South Korea 


\section{General.}

Chemicals and solvents were used as received from Tokyo Chemical Industry (TCI) Co., Wako chemicals, or Sigma-Aldrich Corp. unless otherwise mentioned. $\left[\mathrm{RuCl}_{2}(\mathrm{DMSO})_{4}\right]^{1}$ and di-(2-pyridyl)methane amine ${ }^{2}$ were prepared by literature procedures. N4Py was synthesized with a modified procedure reported in a literature (vide infra). ${ }^{2} \mathrm{UV}$-vis spectra were collected on a Shimadzu UV-3600 spectrophotometer. ${ }^{1} \mathrm{H}$ NMR spectra were recorded on a JEOL EX-270 spectrometer at room temperature and the chemical shifts of signals were determined with respect to residual proton signals of deuterated solvents. Electrochemical measurements were performed with an AUTOLAB PGSTAT12 potentiometer in Britton-Robinson (B.-R.) buffer $(\mathrm{pH}=2 \sim 12)$ at room temperature. $\mathrm{pH}$ measurements were made with a Horiba pH-Meter F-51. The sample solution of complex $\mathbf{6}$ for resonance Raman scattering measurements was prepared with a $2.0 \mathrm{mM}$ solution of $3(50 \mathrm{~mL})$ in $\mathrm{H}_{2}{ }^{16} \mathrm{O}$ or $\mathrm{H}_{2}{ }^{18} \mathrm{O}$, which was oxidized by addition of a $20 \mathrm{mM}$ aqueous solution of CAN (20 mL).

\section{Synthesis of $\quad N, N$-bis(2-pyridylmethyl)- $N$-(bis-2-pyridylmethyl)amine $\quad$ (N4Py). ${ }^{2}$}

Di-(2-pyridyl)methane amine ${ }^{2}(0.90 \mathrm{~g}, 4.9 \mathrm{mmol})$ and picolyl chloride hydrochloride (1.67 g, $10.1 \mathrm{mmol})$ were condensed in $\mathrm{NaOH}(\mathrm{aq})(10 \mathrm{M}, 1 \mathrm{~mL})$ and the mixture was stirred for overnight. The mixture was extracted with $\mathrm{CHCl}_{3}$, and then the solvent of the combined organic phase was evaporated. The obtained oil was purified by column chromatography as a stationary state eluted with $\mathrm{CHCl}_{3}: \mathrm{MeOH}=7: 3$ mixed solvent, and then the solvent of the collected fraction was evaporated under vacuum. Yield: $0.49 \mathrm{~g}(1.3 \mathrm{mmol}, 27 \%)$. ${ }^{1} \mathrm{H}$ NMR $\left(\mathrm{CDCl}_{3}\right): \delta 3.69\left(\mathrm{~s}, 4 \mathrm{H}, \mathrm{CH}_{2}\right), 5.34(\mathrm{~s}, 1 \mathrm{H}, \mathrm{CH}), 7.13(\mathrm{~m}, 4 \mathrm{H}, \mathrm{Py}), 7.62(\mathrm{~m}, 8 \mathrm{H}, \mathrm{Py}), 8.48(\mathrm{~d}, J$ $=7 \mathrm{~Hz}, 2 \mathrm{H}, \mathrm{Py}), 8.57(\mathrm{~d}, J=7 \mathrm{~Hz}, 2 \mathrm{H}, \mathrm{Py})$.

Synthesis of $\left[\mathbf{R u}{ }^{\mathrm{II}} \mathbf{C l}(\mathbf{N} 4 \mathbf{P y})\right]\left(\mathbf{P F}_{6}\right)$. N4Py $(0.37 \mathrm{~g}, 1.0 \mathrm{mmol})$ and $\left[\mathrm{RuCl}_{2}\left(\mathrm{DMSO}_{4}\right]^{1}(0.54 \mathrm{~g}\right.$, $1.0 \mathrm{mmol})$ were charged in a three-necked flask under Ar atmosphere. 2-Propanol $(50 \mathrm{~mL})$ was added with a syringe, and then the solution was refluxed for $14 \mathrm{~h}$. After cooling to room temperature, the solvent was completely removed and the resultant dark-brown material was dissolved in water. Upon addition of excess $\mathrm{NH}_{4} \mathrm{PF}_{6}$, red-brownish solid emerged and the precipitate was filtered and washed with diethyl ether to remove organic materials. The obtained $\left[\mathrm{Ru}^{\mathrm{II}} \mathrm{Cl}(\mathrm{N} 4 \mathrm{Py})\right]\left(\mathrm{PF}_{6}\right)^{3}(0.43 \mathrm{~g}, 0.80 \mathrm{mmol})$ was purified by column chromatography on $\mathrm{Al}_{2} \mathrm{O}_{3}$ as a stationary state eluted with a $\mathrm{CHCl}_{3} / \mathrm{MeOH}(9: 1 \mathrm{v} / \mathrm{v})$ mixed solvent, and then the solvent of the collected fraction was evaporated under vacuum. The residual solid was recrystallized from $\mathrm{MeOH}$, filtered, washed with diethyl ether and then dried in vacuo. Yield: $0.22 \mathrm{~g}(43 \%)$. ESI-MS (methanol): $m / z=504\left(\left[\mathrm{M}-\mathrm{PF}_{6}\right]^{+}\right) .{ }^{1} \mathrm{H}$ NMR $\left(\mathrm{D}_{2} \mathrm{O}\right): \delta 4.31$ and 4.47 $\left.\left(\mathrm{ABq}, J_{\mathrm{AB}}=18,4 \mathrm{~Hz}, 4 \mathrm{H}, \mathrm{N}-\mathrm{CH}_{2}-\mathrm{Py}\right), 6.44(\mathrm{~s}, 1 \mathrm{H}, \mathrm{N}-\mathrm{CH}-\mathrm{Py})_{2}\right), 7.01$ (d, J=8 Hz, 2H, H3 of $\left.P y_{2}-\mathrm{CH}-\mathrm{N}\right), 7.21$ (dd, $J=7,2 \mathrm{~Hz}, 2 \mathrm{H}, \mathrm{H} 5$ of $\left.P y_{2}-\mathrm{CH}-\mathrm{N}\right), 7.32(\mathrm{dd}, J=6,2 \mathrm{~Hz}, 2 \mathrm{H}, \mathrm{H} 5$ of 
$\left.P y-\mathrm{CH}_{2}-\mathrm{N}\right), 7.54$ (t, $J=8 \mathrm{~Hz}, 4 \mathrm{H}, \mathrm{H} 4$ of $\left.P y_{2}-\mathrm{CH}-\mathrm{N}\right), 7.86-7.89\left(\mathrm{~m}, 4 \mathrm{H}, \mathrm{H} 3\right.$ of $P y-\mathrm{CH}_{2}-\mathrm{N}$ and $\mathrm{H} 4$ of $\left.P y-\mathrm{CH}_{2}-\mathrm{N}\right), 8.89\left(\mathrm{~d}, J=6 \mathrm{~Hz}, 2 \mathrm{H}, \mathrm{H} 6\right.$ of $\left.P y-\mathrm{CH}_{2}-\mathrm{N}\right), 9.11(\mathrm{~d}, J=6 \mathrm{~Hz}, 2 \mathrm{H}, \mathrm{H} 6$ of $\left.P y_{2}-\mathrm{CH}-\mathrm{N}\right)$. Elemental analysis calcd $(\%)$ for $\mathrm{C}_{23} \mathrm{H}_{21} \mathrm{~N}_{5} \mathrm{RuClPF}_{6}$ : C 42.57, H 3.26, N 10.79; found: C 42.43, H 3.25, N 10.24; UV-Vis $\left(\mathrm{H}_{2} \mathrm{O}\right): \lambda_{\max }[\mathrm{nm}]=448,366,246$.

Synthesis of $\left[\mathbf{R u}^{\text {II }}(\mathbf{N} 4 \mathbf{P y})\left(\mathbf{O H}_{2}\right)\right]\left(\mathbf{P F}_{\mathbf{6}}\right)_{2} \quad$ (3). An $\mathrm{H}_{2} \mathrm{O}$ solution $(80 \mathrm{~mL})$ containing $[\mathrm{RuCl}(\mathrm{N} 4 \mathrm{Py})]\left(\mathrm{PF}_{6}\right)(0.27 \mathrm{~g}, 0.50 \mathrm{mmol})$ and $\mathrm{AgPF}_{6}(1.26 \mathrm{~g}, 5.0 \mathrm{mmol})$ was refluxed for $3 \mathrm{~h}$. Insoluble white solid was removed by a membrane filter (ADVANTEC H100A025A), and then the solvent of the filtrate was concentrated to a $1 / 10$ volume to obtain a yellow precipitate, The yellow precipitate was recrystallized from a minimal amount of warmed $\mathrm{H}_{2} \mathrm{O}$. The resulting yellow powder was filtered, washed with diethyl ether, and then, dried in vacuo. Yield: $0.22 \mathrm{~g}(56 \%)$. ESI-MS (methanol): $m / z=234\left(\left[\mathrm{M}-\mathrm{H}_{2} \mathrm{O}-2 \mathrm{PF}_{6}\right]^{2+}\right) .{ }^{1} \mathrm{H}$ NMR $\left(\mathrm{D}_{2} \mathrm{O}\right): \delta$ 4.31 and $4.44\left(\mathrm{ABq}, J_{\mathrm{AB}}=18,4 \mathrm{~Hz}, 4 \mathrm{H}, \mathrm{N}-\mathrm{CH}_{2}-\mathrm{Py}\right), 6.44\left(\mathrm{~s}, 1 \mathrm{H}, \mathrm{N}-\mathrm{CH}-\mathrm{Py}_{2}\right), 7.05$ (d, $J=8$ $\mathrm{Hz}, 2 \mathrm{H}, \mathrm{H} 3$ of $P y_{2}-\mathrm{CH}-\mathrm{N}$ ), 7.29 (dd, $J=7,2 \mathrm{~Hz}, 2 \mathrm{H}, \mathrm{H} 5$ of $\left.P y_{2}-\mathrm{CH}-\mathrm{N}\right), 7.37$ (dd, $J=6,2 \mathrm{~Hz}$, $2 \mathrm{H}, \mathrm{H} 5$ of $\left.P y-\mathrm{CH}_{2}-\mathrm{N}\right), 7.59\left(\mathrm{t}, J=7 \mathrm{~Hz}, 4 \mathrm{H}, \mathrm{H} 4\right.$ of $\left.P y_{2}-\mathrm{CH}-\mathrm{N}\right), 7.90-7.94(\mathrm{~m}, 4 \mathrm{H}, \mathrm{H} 3$ of $P y-\mathrm{CH}_{2}-\mathrm{N}$ and $\mathrm{H} 4$ of $\left.P y-\mathrm{CH}_{2}-\mathrm{N}\right), 8.83\left(\mathrm{~d}, J=6 \mathrm{~Hz}, 2 \mathrm{H}, \mathrm{H} 6\right.$ of $\left.P y-\mathrm{CH}_{2}-\mathrm{N}\right), 8.93(\mathrm{~d}, J=6 \mathrm{~Hz}$, $2 \mathrm{H}$, H6 of $\left.P y_{2}-\mathrm{CH}-\mathrm{N}\right)$. Anal.: calcd $(\%)$ for $\mathrm{C}_{23} \mathrm{H}_{23} \mathrm{~N}_{5} \mathrm{ORuP}_{2} \mathrm{~F}_{12}: \mathrm{C} 35.58, \mathrm{H} 2.99$, N 9.02; found: C 35.43, H 3.07, N 9.07. UV-Vis $\left(\mathrm{H}_{2} \mathrm{O}\right): \lambda_{\max }[\mathrm{nm}]=439,361,246$.

Synthesis of $\left[\mathbf{R u}^{\mathrm{IV}}(\mathbf{O})(\mathbf{N} 4 \mathrm{Py})\right]\left(\mathbf{P F}_{6}\right)_{2}(\mathbf{6})$. The oxo complex 6 was formed by the treatment of $3(0.77 \mathrm{mg}, 1.0 \mu \mathrm{mol})$ with 10 equiv of CAN $(5.4 \mathrm{mg}, 10 \mu \mathrm{mol})$ in $\mathrm{D}_{2} \mathrm{O}(0.5 \mathrm{~mL})$ for ${ }^{1} \mathrm{H} \mathrm{NMR}$ spectroscopy. In addition, ${ }^{18} \mathrm{O}$-labeled oxo complex 6 was produced by the reaction of $3(0.77$ $\mathrm{mg}, 1.0 \mu \mathrm{mol})$ with an excess amount of CAN $(5.4 \mathrm{mg}, 10 \mu \mathrm{mol})$ in $\mathrm{H}_{2}{ }^{18} \mathrm{O}(0.5 \mathrm{~mL})$ for ESI-MS spectrometry. ESI-MS $\left(\mathrm{H}_{2} \mathrm{O}\right): m / z=242.5\left(\left[\mathrm{M}-2 \mathrm{PF}_{6}\right]^{2+}\right) ;\left(\mathrm{H}_{2}{ }^{18} \mathrm{O}\right): m / z=243.5([\mathrm{M}-$ $\left.\left.2 \mathrm{PF}_{6}\right]^{2+}\right) .{ }^{1} \mathrm{H} \mathrm{NMR}\left(\mathrm{D}_{2} \mathrm{O}\right): \delta 5.26$ and $5.68\left(\mathrm{ABq}, J_{\mathrm{AB}}=17,4 \mathrm{~Hz}, 4 \mathrm{H}, \mathrm{N}-\mathrm{CH}_{2}-\mathrm{Py}\right), 7.35(\mathrm{~d}, J=$ $8 \mathrm{~Hz}, 2 \mathrm{H}, \mathrm{H} 3$ of $\left.P y_{2}-\mathrm{CH}-\mathrm{N}\right), 7.41$ (s, 1H, N-CH-Py2), 7.50 (dd, $J=7,2 \mathrm{~Hz}, 2 \mathrm{H}, \mathrm{H} 5$ of $\left.P y_{2}-\mathrm{CH}-\mathrm{N}\right), 7.63$ (dd, $J=6,2 \mathrm{~Hz}, 2 \mathrm{H}, \mathrm{H} 5$ of $\left.P y-\mathrm{CH}_{2}-\mathrm{N}\right), 7.82(\mathrm{dd}, J=8,4 \mathrm{~Hz}, 4 \mathrm{H}, \mathrm{H} 4$ of $\left.P y_{2}-\mathrm{CH}-\mathrm{N}\right), 8.10-8.22$ (m, 4H, H3 of $P y-\mathrm{CH}_{2}-\mathrm{N}$ and $\mathrm{H} 4$ of $\left.P y-\mathrm{CH}_{2}-\mathrm{N}\right), 8.43(\mathrm{~d}, J=6 \mathrm{~Hz}, 2 \mathrm{H}$, H6 of $\left.P y-\mathrm{CH}_{2}-\mathrm{N}\right), 9.00\left(\mathrm{~d}, J=6 \mathrm{~Hz}, 2 \mathrm{H}, \mathrm{H} 6\right.$ of $\left.P y_{2}-\mathrm{CH}-\mathrm{N}\right)$. UV-vis $\left(\mathrm{H}_{2} \mathrm{O}\right): \lambda_{\max }[\mathrm{nm}]=264$. Resonance Raman: $v\left[\mathrm{~cm}^{-1}\right]=801\left(\mathrm{H}_{2}{ }^{16} \mathrm{O}\right) ; v\left[\mathrm{~cm}^{-1}\right]=761\left(\mathrm{H}_{2}{ }^{18} \mathrm{O}\right)$.

Iodometry of CAN. The concentration of $\mathrm{Na}_{2} \mathrm{~S}_{2} \mathrm{O}_{3}$ (aq) was determined to be $22.3 \mathrm{mM}$ by titration of the solution into $3.4 \mathrm{mM}$ aqueous $\mathrm{KIO}_{3}$ solution in the presence of excess $\mathrm{KI}$ and starch, where the completion was indicated by disappearance of the purple color of the $\mathrm{I}_{3}$-starch complex. Then, into CAN $(122.7 \mathrm{mg})$ solution in $\mathrm{H}_{2} \mathrm{O}(10 \mathrm{~mL})$, to which was added excess KI and starch, was titrated the above $\mathrm{Na}_{2} \mathrm{~S}_{2} \mathrm{O}_{3}$ solution. The purity of CAN was determined to be $95 \%$. 
Reduction potential of CAN. ${ }^{4}$ Reduction potential of CAN was obtained by differential pulse voltammograms (DPV) in $0.1 \mathrm{M} \mathrm{NaClO}_{4}(\mathrm{aq})(\mathrm{pH}=5.68)$ at room temperature, where the concentration of CAN was $1.0 \mathrm{mM}$ and the scan rate was $0.1 \mathrm{~V} / \mathrm{s}$. The reduction potential was determined to be $+1.1 \mathrm{~V}$ relative to SCE.

Resonance Raman Spectroscopy. The resonance Raman spectra of complex 6 were measured as follows: To a $50 \mu \mathrm{L}$ of $\mathrm{H}_{2}{ }^{16} \mathrm{O}$ or $\mathrm{H}_{2}{ }^{18} \mathrm{O}$ solution of $3(2.0 \mathrm{mM})$, was added a 20 $\mu \mathrm{L}$ aqueous solution of CAN (20 mM). Resonance Raman scattering was excited at $363.8 \mathrm{~nm}$ from an $\mathrm{Ar}^{+}$laser (Spectra Physics, 2080-25), dispersed by a single polychromator (Ritsu Oyo Kogaku, MC-100DG) and detected by a liquid-nitrogen-cooled CCD detector (Roper Scientific, LNCCD-1100-PB). The resonance Raman measurements were carried out at $22^{\circ} \mathrm{C}$ using a spinning NMR tube (outer diameter $=5 \mathrm{~mm}$, wall thickness $=0.24 \mathrm{~mm}$ ) at $135^{\circ}$ back-scattering geometry.

X-ray Crystallography on $\left[\mathrm{Ru}(\mathbf{N} 4 \mathrm{Py})\left(\mathrm{OH}_{2}\right)\right]\left(\mathbf{P F}_{6}\right)_{2} \quad(3) . \quad$ A single crystal of $\left[\mathrm{Ru}(\mathrm{N} 4 \mathrm{Py})\left(\mathrm{OH}_{2}\right)\right]\left(\mathrm{PF}_{6}\right)_{2}(3)$ was obtained by recrystallization with slow evaporation of the $\mathrm{CH}_{2} \mathrm{Cl}_{2}$ solution in the presence of octane as a poor solvent. All measurements were performed at $120 \mathrm{~K}$ on a Bruker APEXII Ultra diffractometer. The structure was solved by a direct method (SIR-97) and expanded with differential Fourier technique. All non-hydrogen atoms were refined anisotropically and the refinement was carried out with full matrix least squares on $F$. All calculations were performed using the Yadokari-XG crystallographic software package. ${ }^{5}$ Crystallographic data: $\mathrm{C}_{23} \mathrm{H}_{23} \mathrm{~N}_{5} \mathrm{ORu} \cdot 2 \mathrm{PF}_{6} \cdot \mathrm{CH}_{2} \mathrm{Cl}_{2}, \mathrm{FW}=902.86$, red-orange, monoclinic, $P 2_{1} / n, a=11.3277(18) \AA, b=18.234(3) \AA, c=15.932(3) \AA, \beta=$ 97.573(2) $)^{\circ}, V=3262.1(9) \AA^{3}, Z=4, D_{\text {calcd }}=1.838 \mathrm{~g} \mathrm{~cm}^{-3}, F_{000}=1792, R 1=0.0512(I$ $>2.00 \sigma(I)), w R=0.1407$ (all data), GOF $=1.033$. CCDC-875411 contains the supplementary crystallographic data. This data can be obtained free of charge from the Cambridge Crystallographic Data Centre via www.ccdc. cam.ac.uk/data_request/cif.

\section{Reference and Notes.}

1. E. Duliere, M. Devillers and J. Marchand-Brynaert, Organometallics 2003, 22, 804.

2. M. Lubben, A. Meetsma, E. C. Wilkinson, B. Feringa and L. Que, Jr. Angew. Chem., Int. Ed. Engl. 1995, 34, 1512.

3. T. Kojima, D. M. Weber and C. T. Choma, Acta Cryst. 2005, E61, m226.

4. V. Sridharan and J. C. Menéndez, Chem. Rev. 2010, 110, 3805.

5. (a) K. Wakita, Yadokari-XG, Software for Crystal Structure Analyses, 2001; (b) C. Kabuto, S. Akine, T. Nemoto and E. Kwon, J. Cryst. Soc. Jpn. 2009, 51, 218. 
Table S1 Selected bond lengths $(\AA)$ and angles $\left(^{\circ}\right)$ of $\mathbf{3}$.

\begin{tabular}{ccccc}
\hline \multicolumn{2}{c}{ Bond lengths $(\AA)$} & & O1-Ru-N4 & $97.48(19)$ \\
Ru-O1 & $2.172(5)$ & & O1-Ru-N5 & $98.97(18)$ \\
Ru-N1 & $1.967(5)$ & & N1-Ru-N2 & $82.22(17)$ \\
Ru-N2 & $2.057(4)$ & & N1-Ru-N3 & $81.91(17)$ \\
Ru-N3 & $2.052(4)$ & & N1-Ru-N4 & $83.16(18)$ \\
Ru-N4 & $2.061(4)$ & & N1-Ru-N5 & $83.33(17)$ \\
Ru-N5 & $2.060(5)$ & & N2-Ru-N3 & $85.62(17)$ \\
& & & N2-Ru-N4 & $165.38(18)$ \\
Bond angles $\left({ }^{\circ}\right)$ & N2-Ru-N5 & $90.69(17)$ \\
O1-Ru-N1 & $177.63(18)$ & N3-Ru-N4 & $92.25(17)$ \\
O1-Ru-N3 & $97.12(18)$ & N3-Ru-N5 & $165.14(19)$ \\
\hline
\end{tabular}


(a)

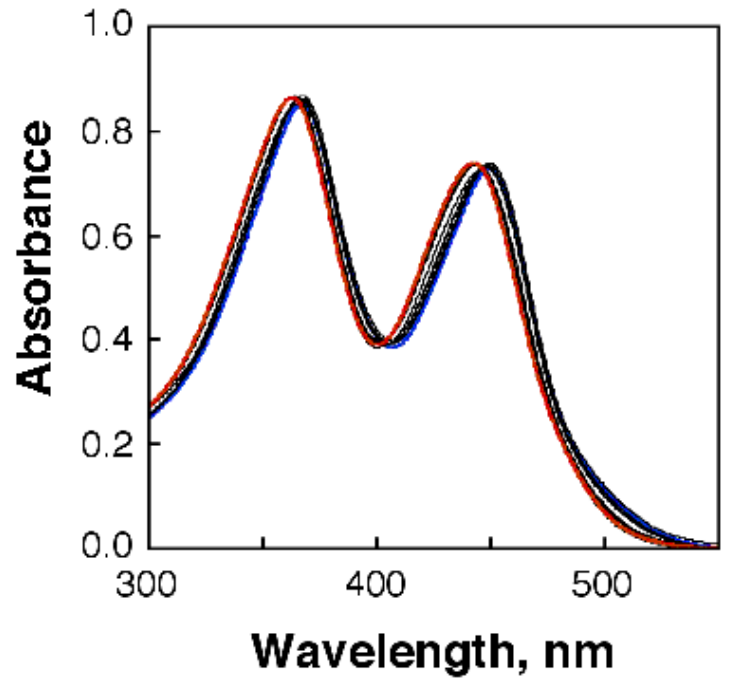

(c)

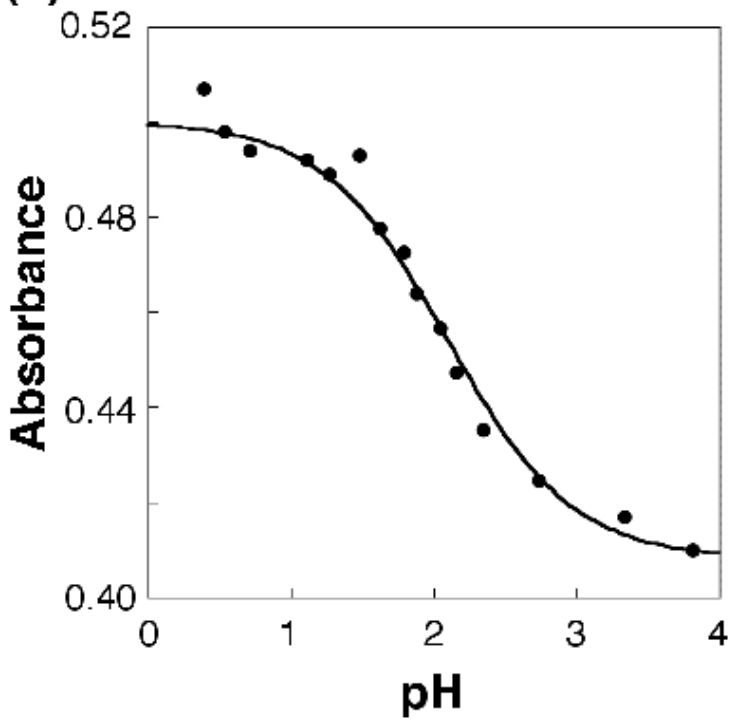

(b)

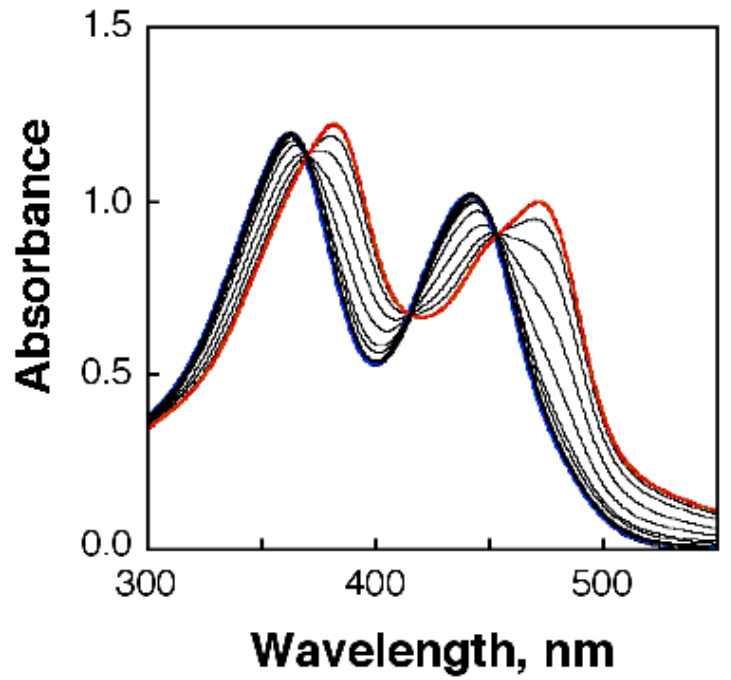

(d)

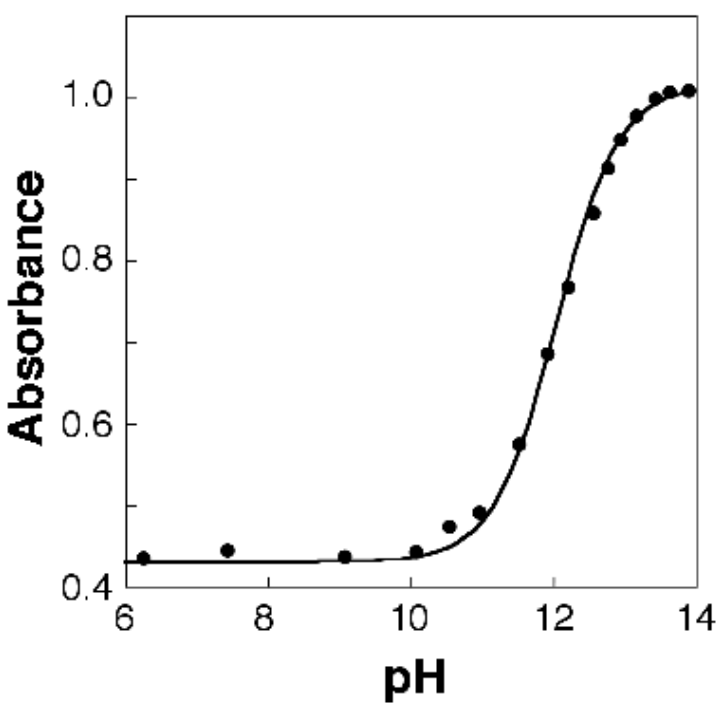

Fig. S1 Spectral changes during pH titration of 3 in B.-R. buffer (sample concentration: 0.1 $\mathrm{mM}$ ) at room temperature. The spectral changes in the $\mathrm{pH}$ range (a) of 0.4-3.8 and (b) of 6.214.2 and the plot of the absorbance change at $470 \mathrm{~nm}$ relative to $\mathrm{pH}$ in the range (c) of $\mathrm{pH}=$ $0.4-3.8$ and $(\mathrm{d})$ of $\mathrm{pH}=6.2-14.2$. 


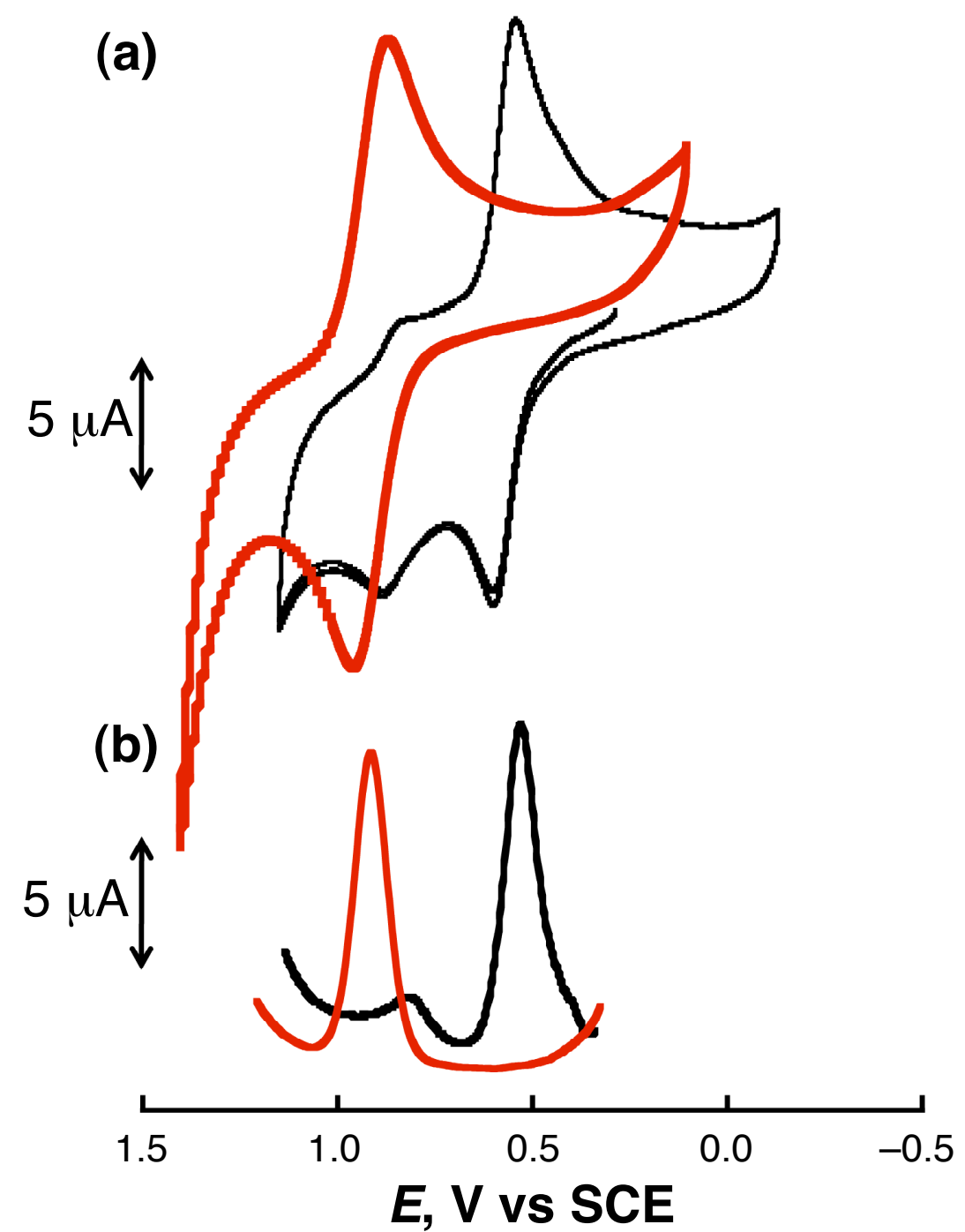

Fig. S2 (a) Cyclic and (b) differential pulse voltammograms of $\mathbf{3}$ (black lines) and $\left[\mathrm{Ru}^{\mathrm{II}}(\mathrm{bpy})_{3}\right] \mathrm{Cl}_{2}$ (red lines) in B.-R. buffer $(1.0 \mathrm{mM})$ at $\mathrm{pH} 2.72$ at room temperature. Scan rate for CV: $0.1 \mathrm{~V} \mathrm{~s}^{-1}$. 

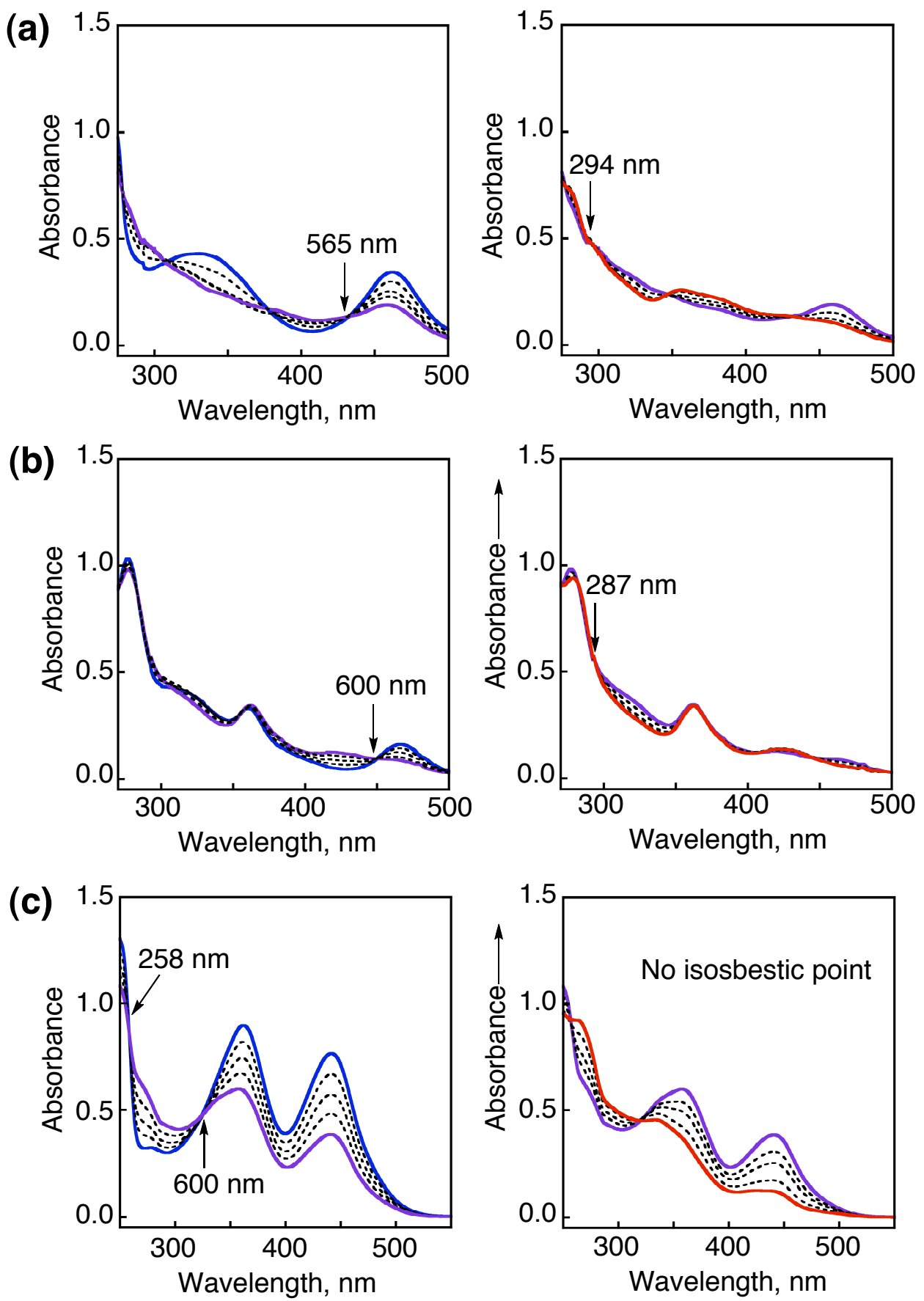

Fig. S3 Spectral changes of every 7.5 min during the electrochemical oxidation of a) 1, b) 2 , and c) 3 in B.-R. buffer ( $\mathrm{pH} \mathrm{1.8,} \mathrm{sample} \mathrm{concentration:} 0.5 \mathrm{mM}$ ) at room temperature. The left graphs indicate the changes during the reactions for the first $30 \mathrm{~min}(0-30 \mathrm{~min})$ and the right ones show the changes for the latter $30 \mathrm{~min}$ (30-60 min). The initial, the medium and the final spectra of each complex are indicated as the blue, purple and red lines in the graphs, respectively. 


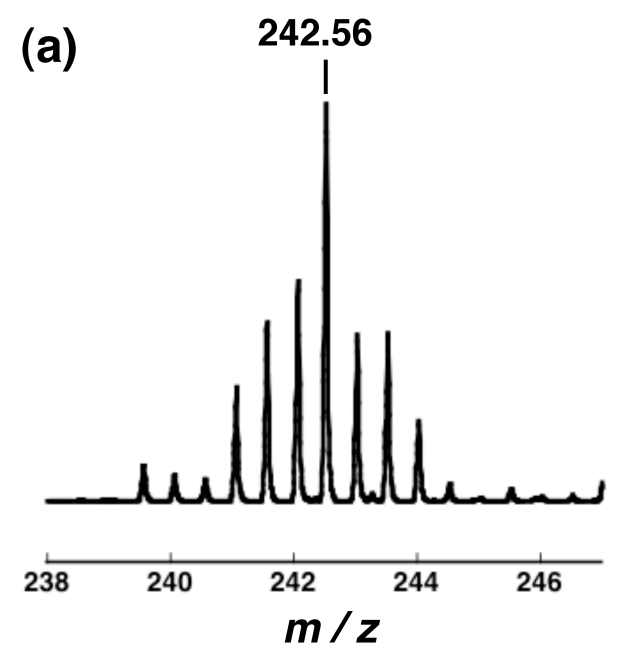

(c)

242.54

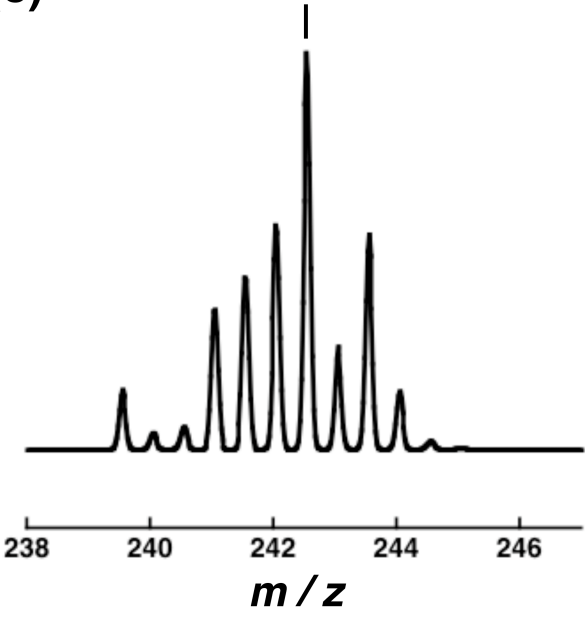

(b)

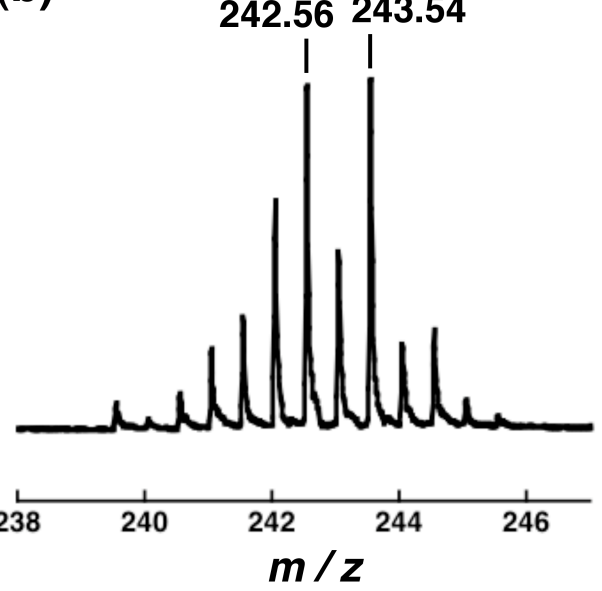

(d)

242.54243 .54
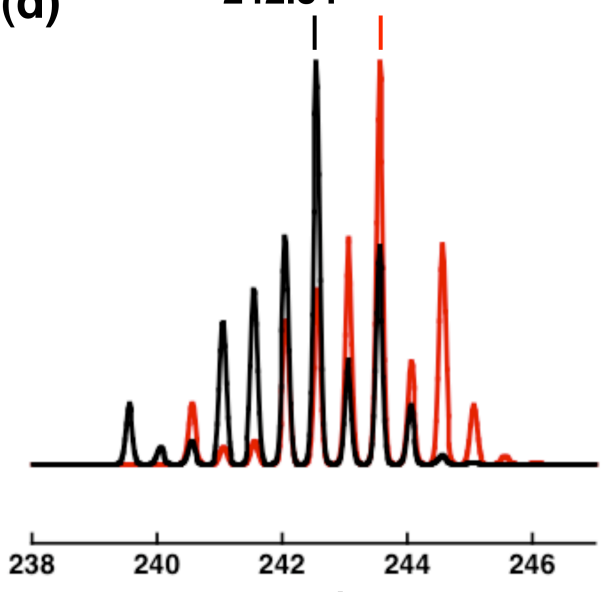

Fig. S4 ESI-TOF MS spectra of 6 a) in $\mathrm{H}_{2}{ }^{16} \mathrm{O}$ and b) in $\mathrm{H}_{2}{ }^{18} \mathrm{O}$ and their computer simulations (c and d). 


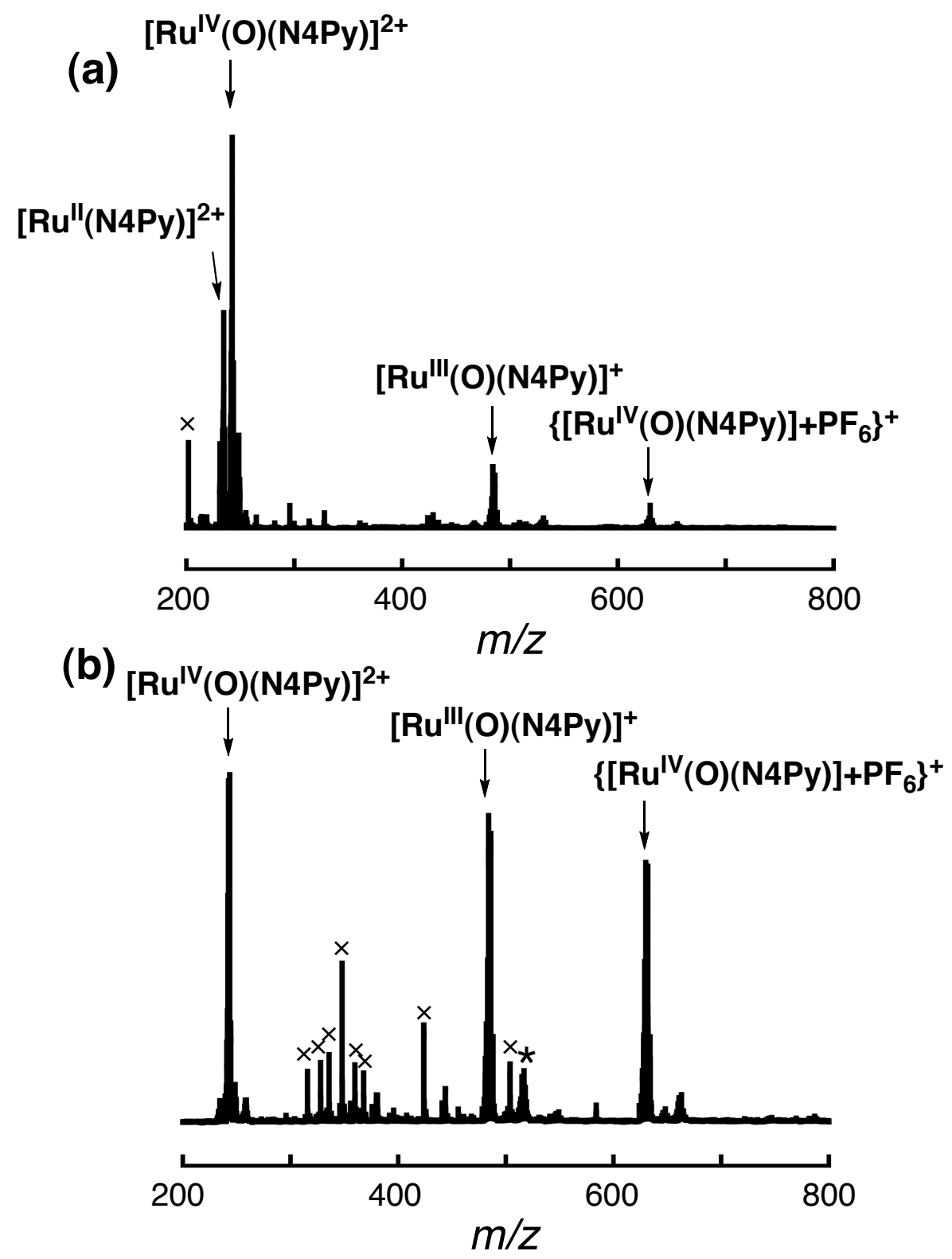

Fig. S5 ESI-TOF MS spectra of 6 a) in $\mathrm{H}_{2} \mathrm{O}$ and b) in $\mathrm{H}_{2}{ }^{18} \mathrm{O}$. The asterisk denotes non-assignable $\mathrm{Ru}$-species and the crosses $(x)$ indicate signals due to organic species. 

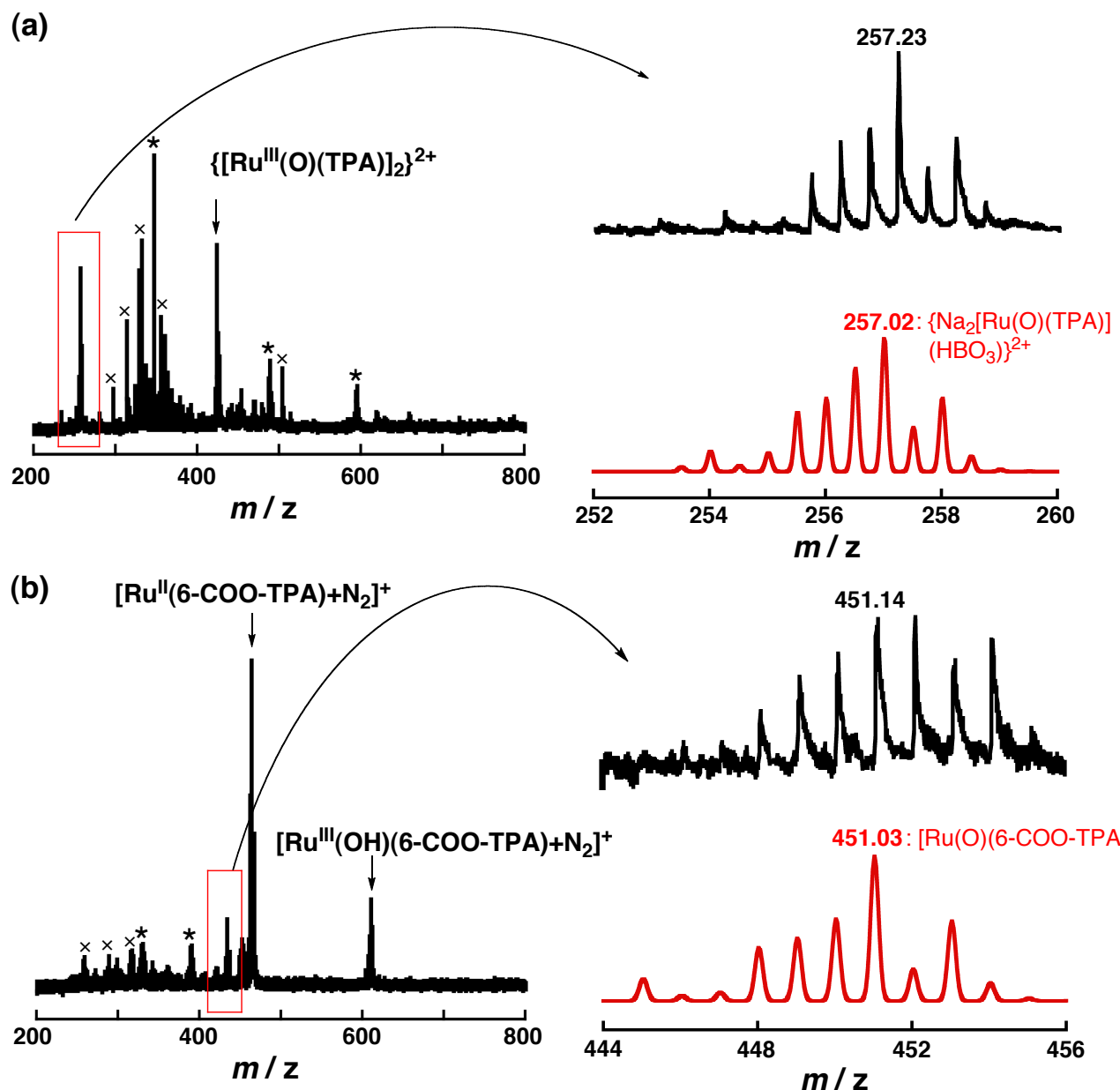

(c)
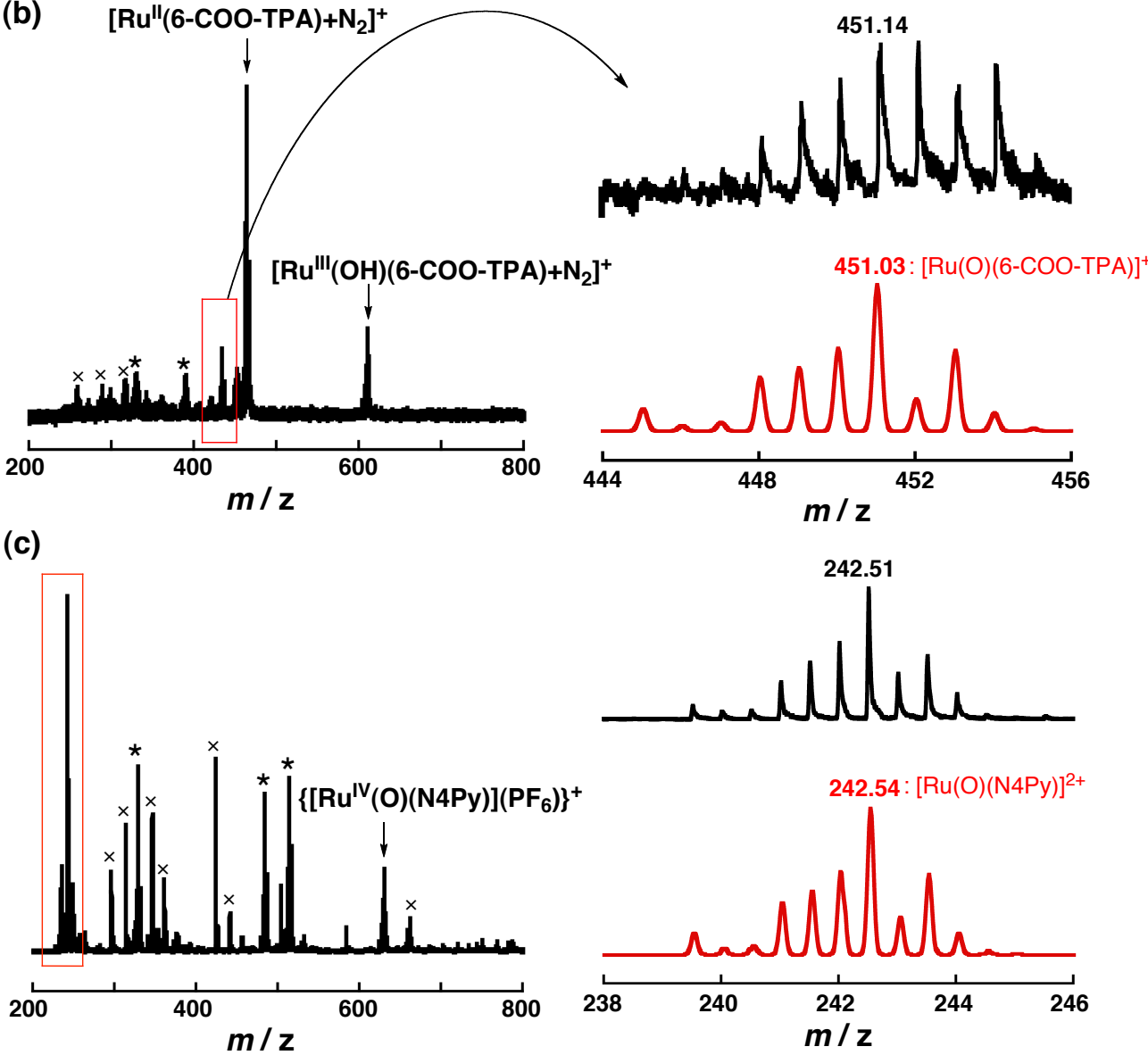

Fig. S6 ESI-MS spectra of electrochemically generated (a) 4, (b) 5 and (c) 6 in $\mathrm{H}_{2} \mathrm{O}$ (left, and right above) and their computer simulation (right below). *: non-assignable Ru-species, $x$ : organic species. 


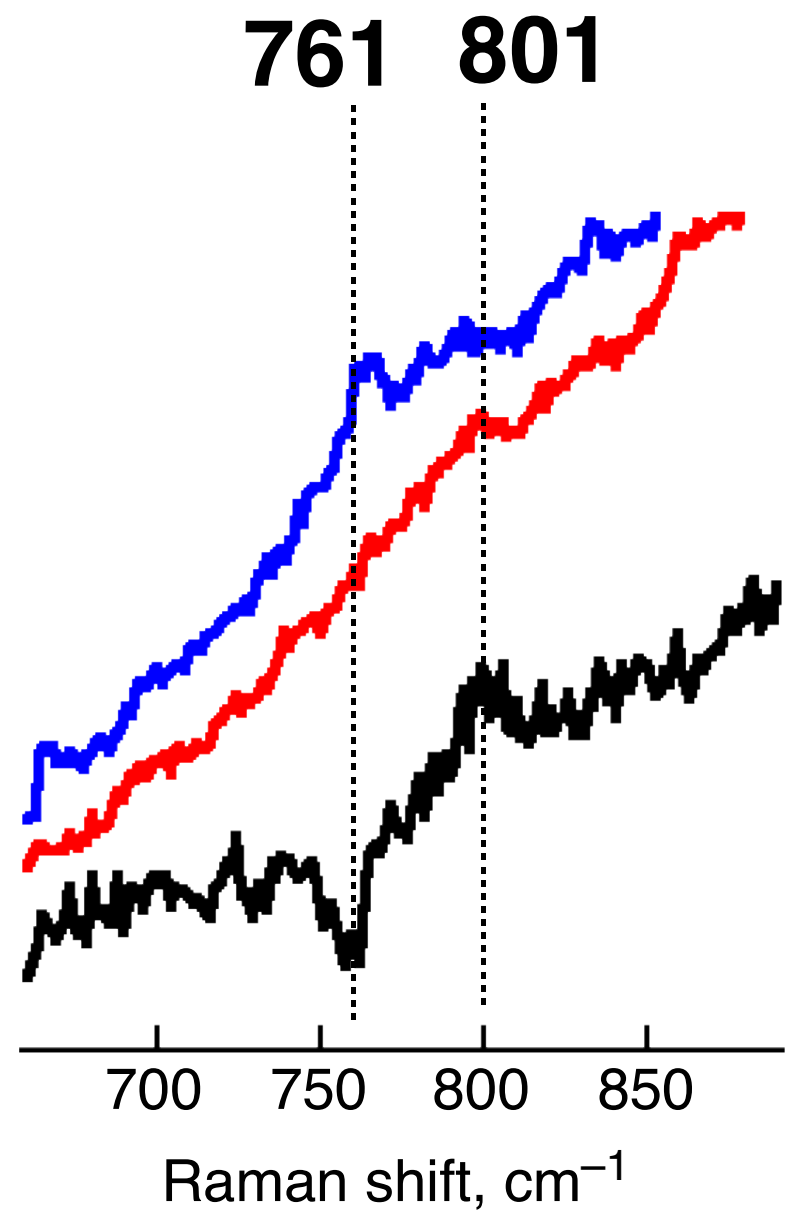

Fig. S7 Resonance Raman spectra of 6 generated in $\mathrm{H}_{2}{ }^{16} \mathrm{O}\left(801 \mathrm{~cm}^{-1}\right.$, red line $)$ and in $\mathrm{H}_{2}{ }^{18} \mathrm{O}$ (761 $\mathrm{cm}^{-1}$, blue line), and the differential spectrum: (black) $=($ red $)-($ blue $) ; 3(2 \mathrm{mmol})$ and CAN $(20 \mathrm{mmol})$ in water $(70 \mu \mathrm{L})$. 
(a)

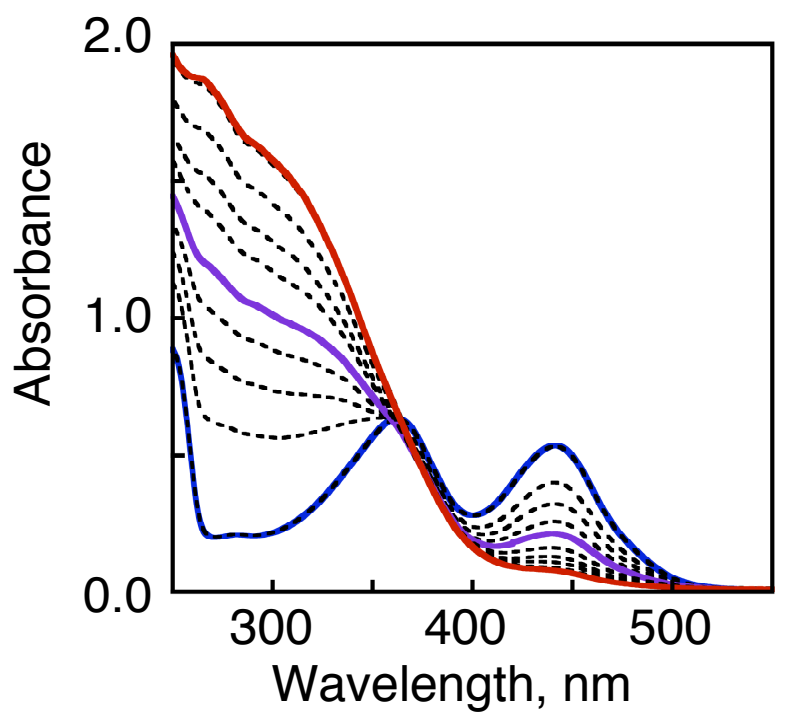

(b)

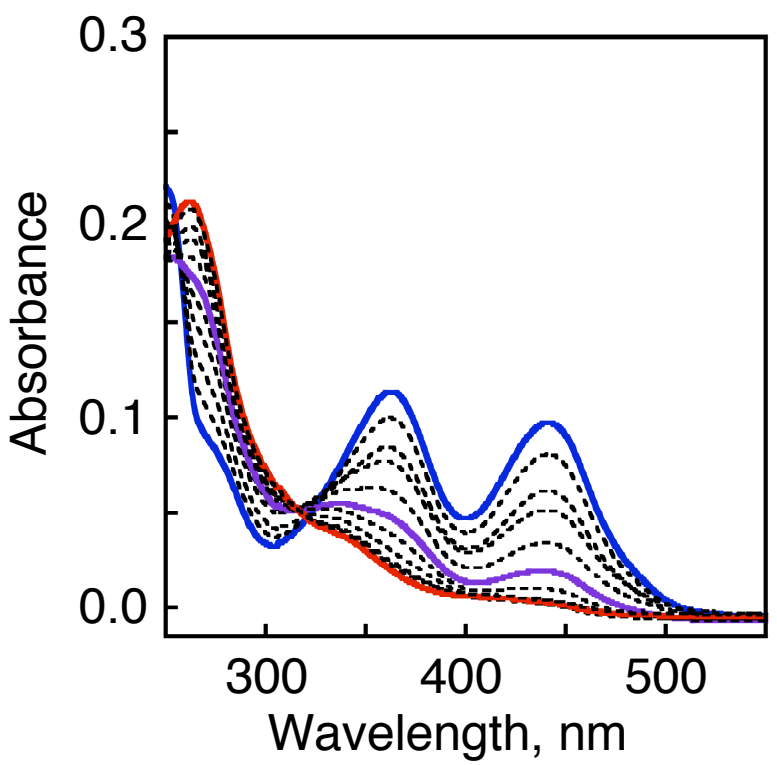

Fig. $\mathbf{S 8}$ Spectral changes during the chemical oxidation of $\mathbf{3}$ (sample concentration: $0.05 \mathrm{mM}$ ) a) in neutral water and b) in B.-R. buffer ( $\mathrm{pH}$ 1.8) at room temperature. The initial spectrum of each graph is indicated as the blue red lines, respectively. The purple and red lines in each graph indicate the spectra at the stages upon addition of 5 eq and 10 eq of CAN for graph a, and those upon addition of 1 eq and 2 eq for graph $b$, respectively. 


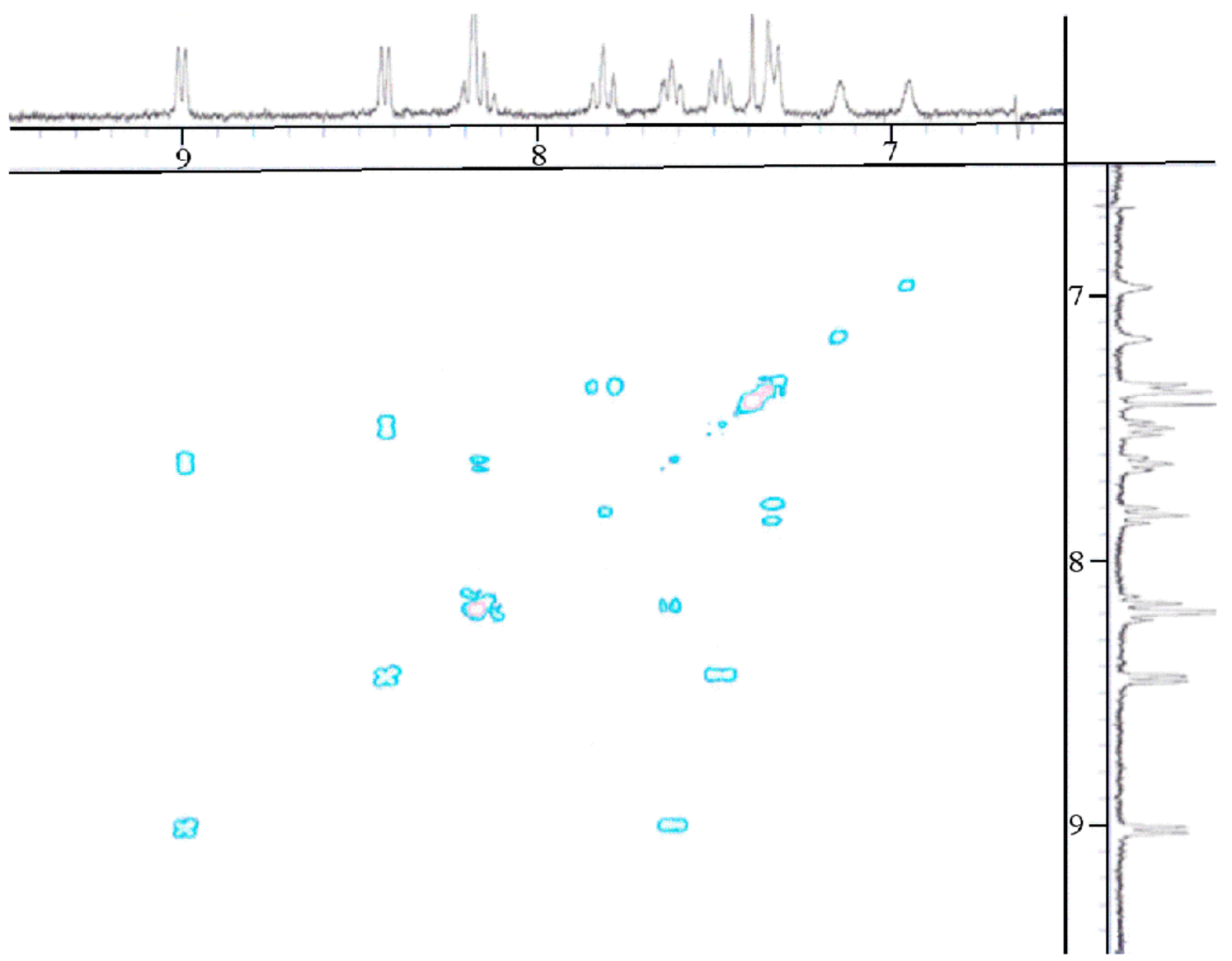

Fig. $\boldsymbol{S 9}{ }^{1} \mathrm{H}^{1} \mathrm{H}$ COSY spectrum of complex 6 in $\mathrm{D}_{2} \mathrm{O}$ at room temperature. 

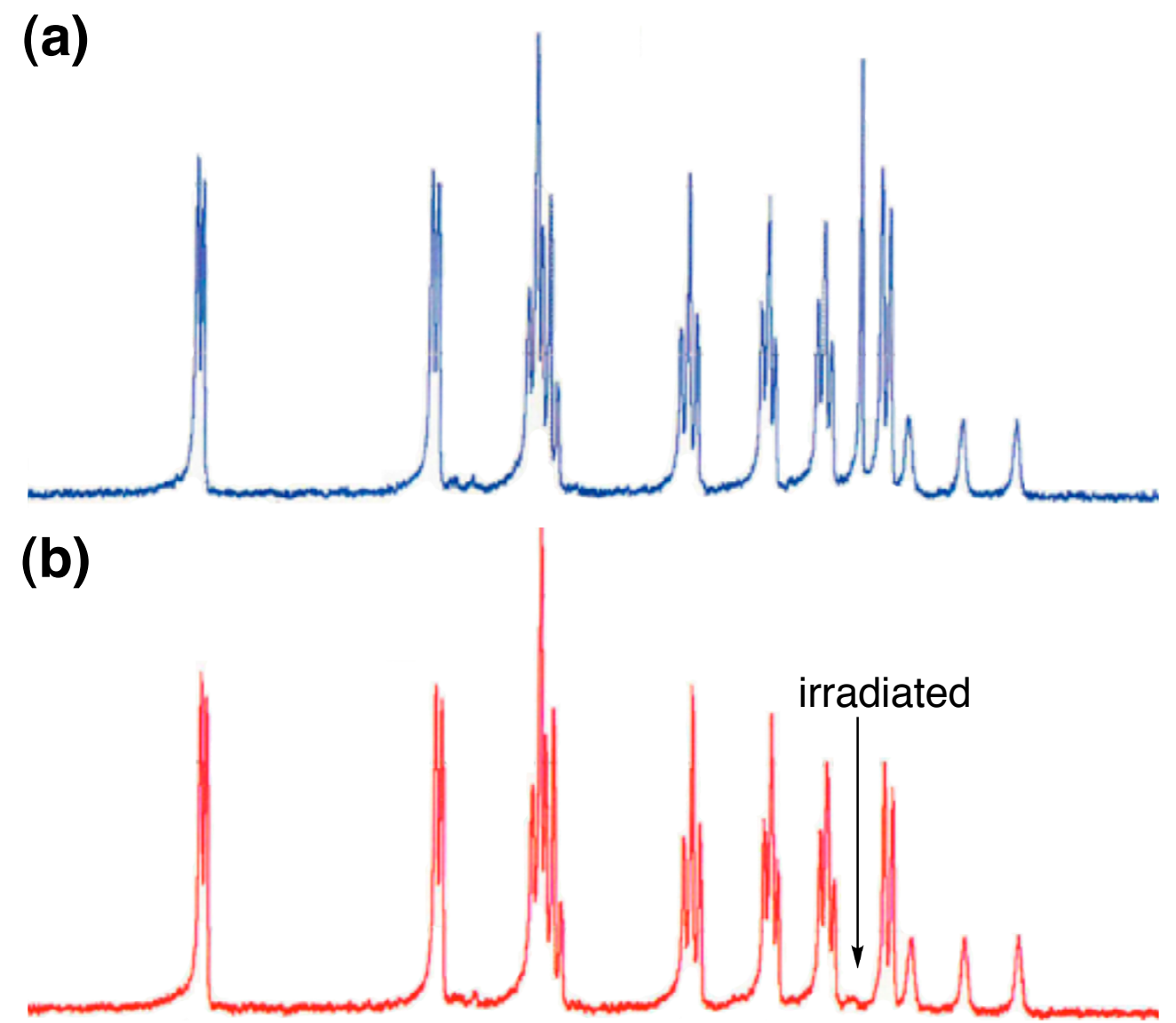

(c)

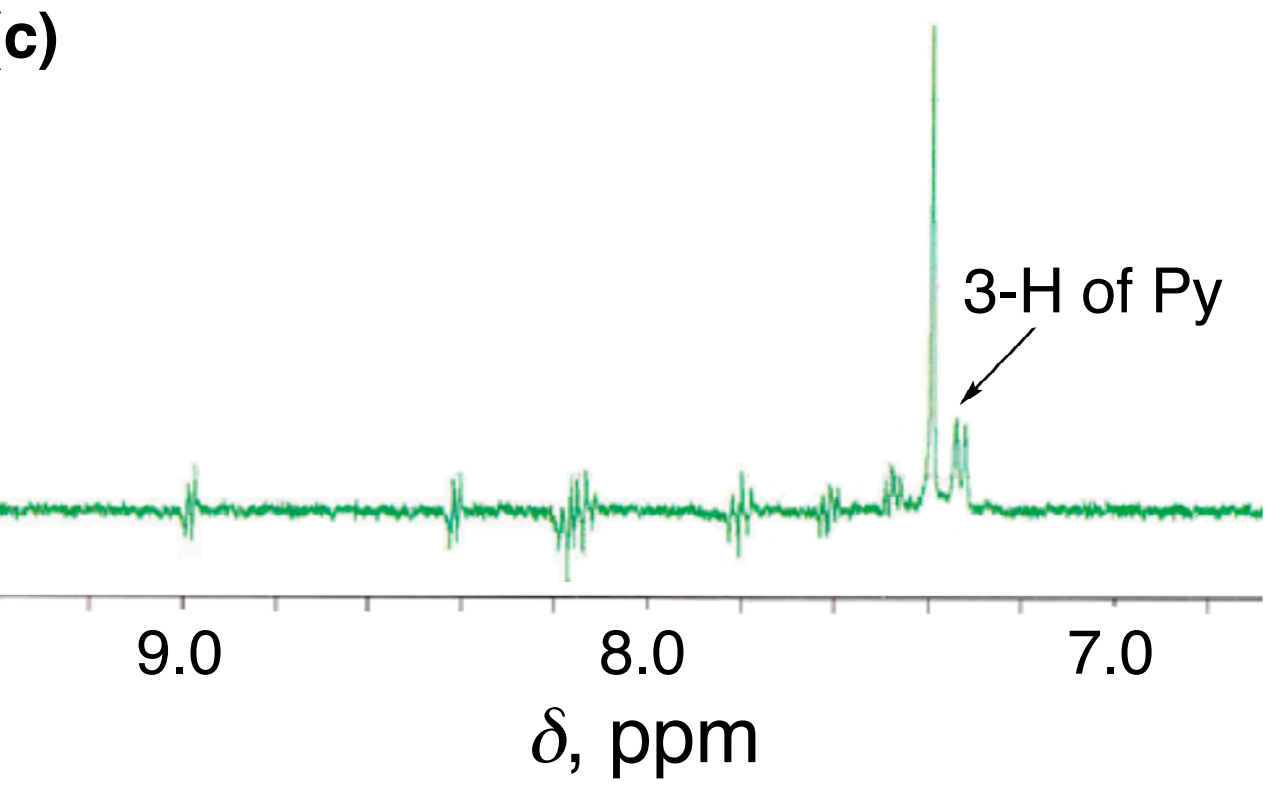

Fig. S10 1D NOE measurements on complex 6 in $\mathrm{D}_{2} \mathrm{O}$ at room temperature with irradiation at 7.4 ppm: The spectrum a) without irradiation; b) with irradiation at $7.4 \mathrm{ppm}$; $)$ the differential spectrum $(a-b)$. 
(a)

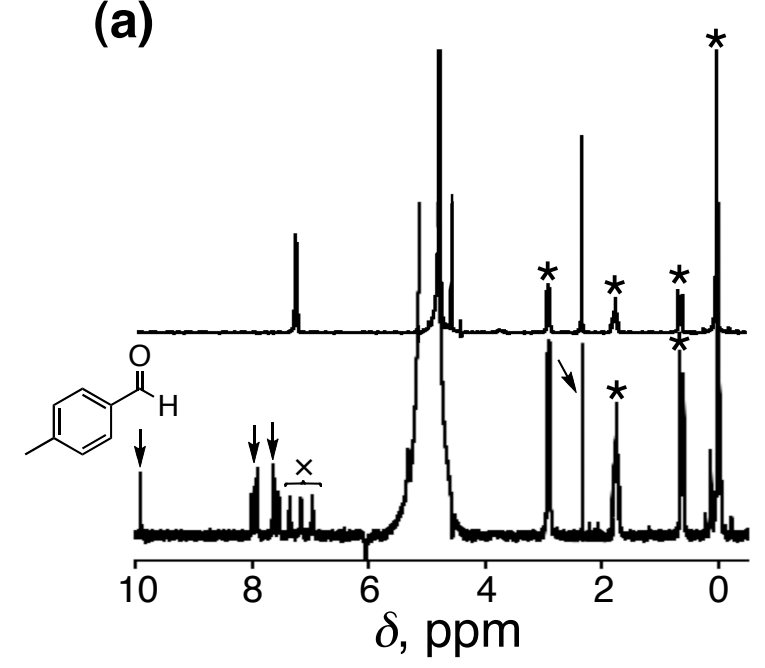

(c)

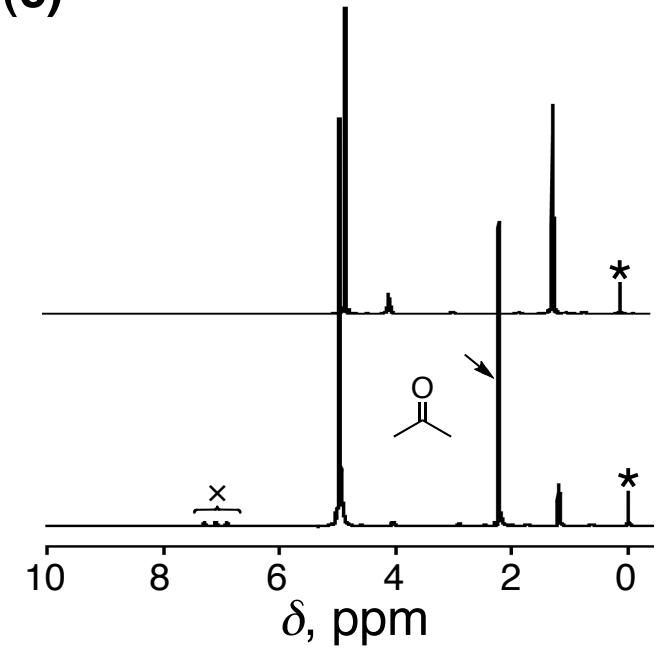

(b)

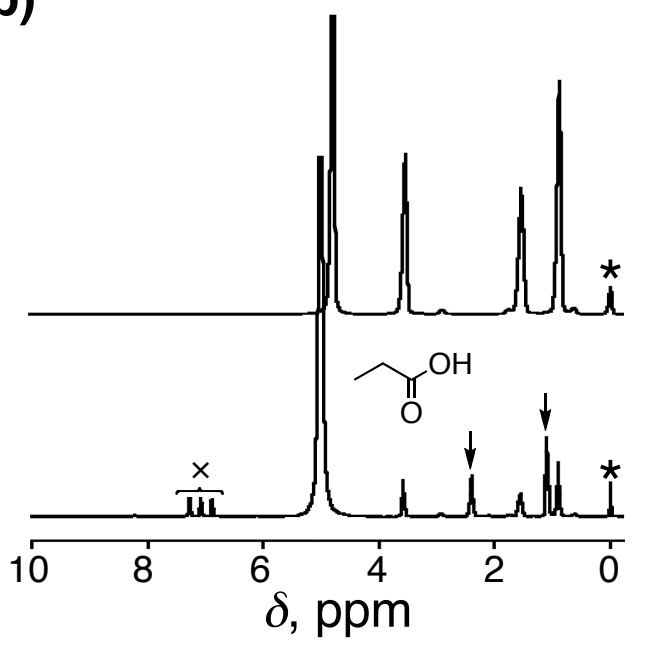

(d)

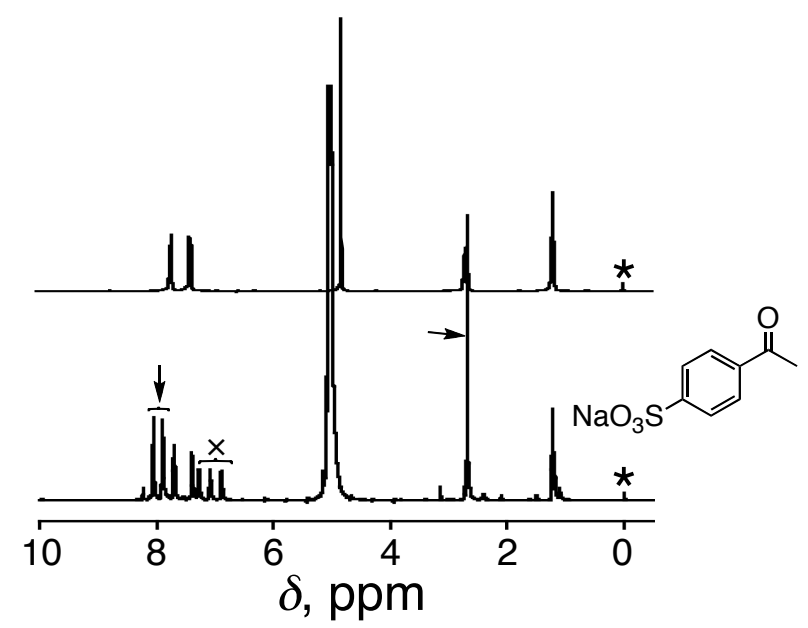

Fig. S11 ${ }^{1} \mathrm{H}$ NMR spectra in $\mathrm{D}_{2} \mathrm{O}$ of catalytic oxidations of a) 4-methylbenzyl alcohol, b) 1-propanol, c) 2-propanol, d) sodium 4-ethylbenzene-sulfonate as substrates in the presence of $\mathbf{1}$ as a catalyst and CAN as the oxidant. Arrows indicate the signals of each product. *: DSS as an internal reference, $x$ : ammonium ion of CAN. 

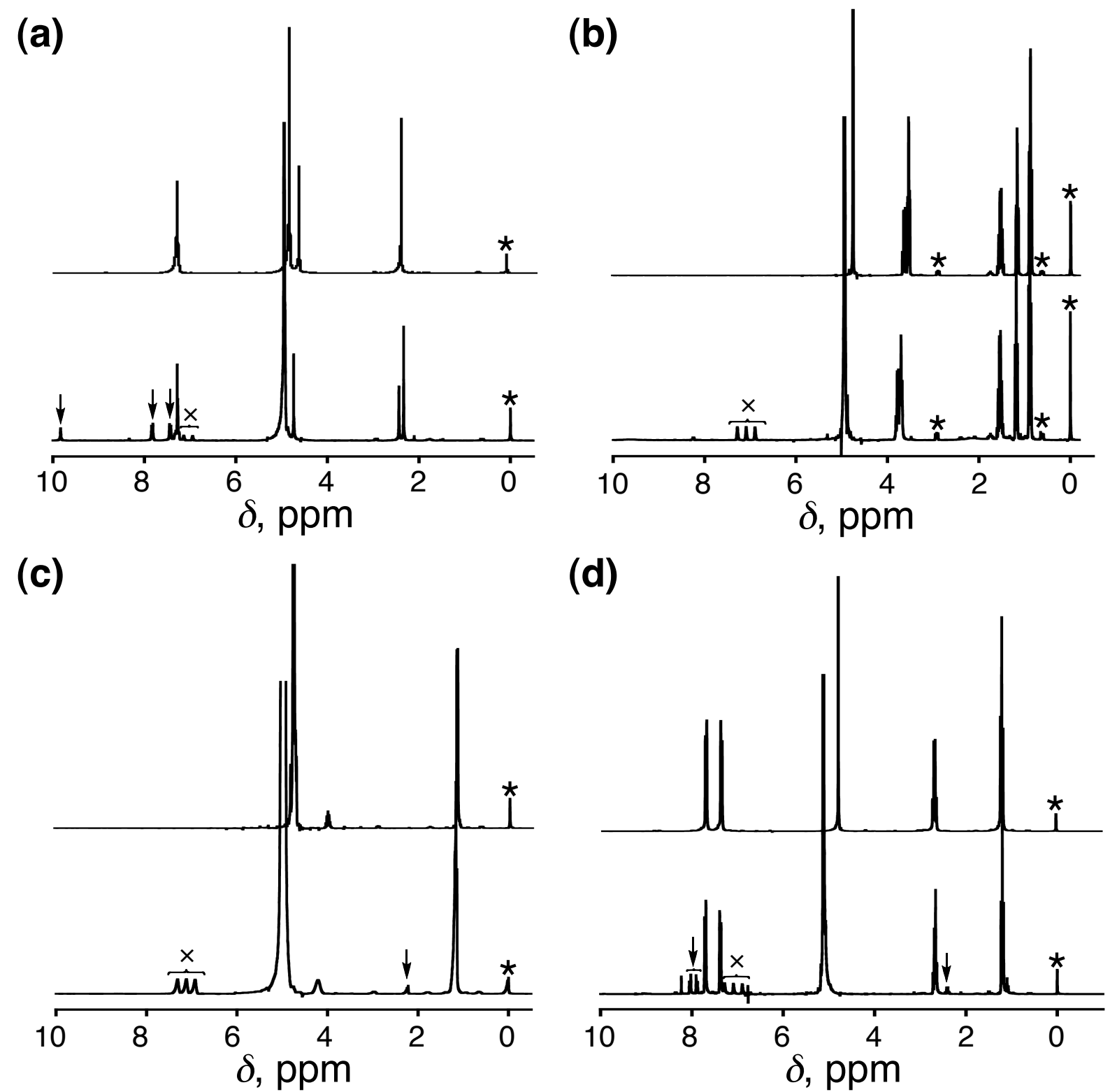

Fig. S12 ${ }^{1}$ H NMR spectra of the control experiments without catalysts for the oxidation of a) 4-methylbenzyl alcohol, b) 1-propanol, c) 2-propanol, d) sodium 4-ethylbenzene-sulfonate as substrates in the presence of CAN as the oxidant. Arrows indicate the signals of each product. *: DSS as an internal reference, $\mathrm{x}$ : ammonium ion of CAN. 
(a)

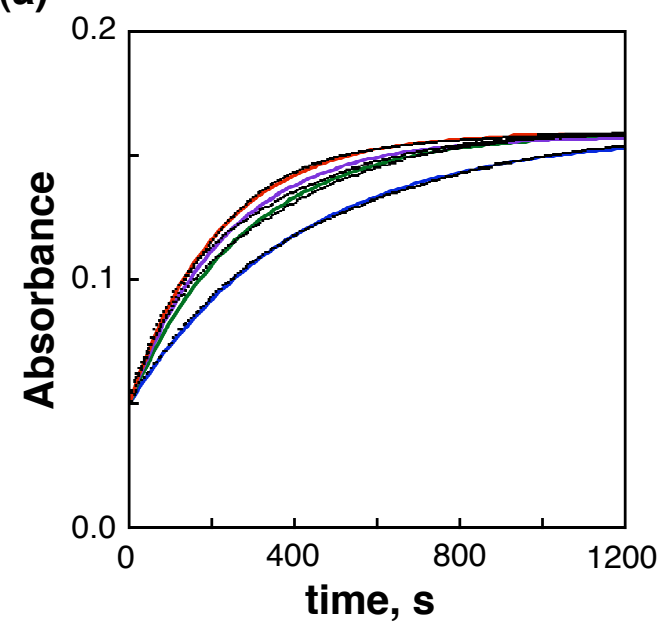

(b)

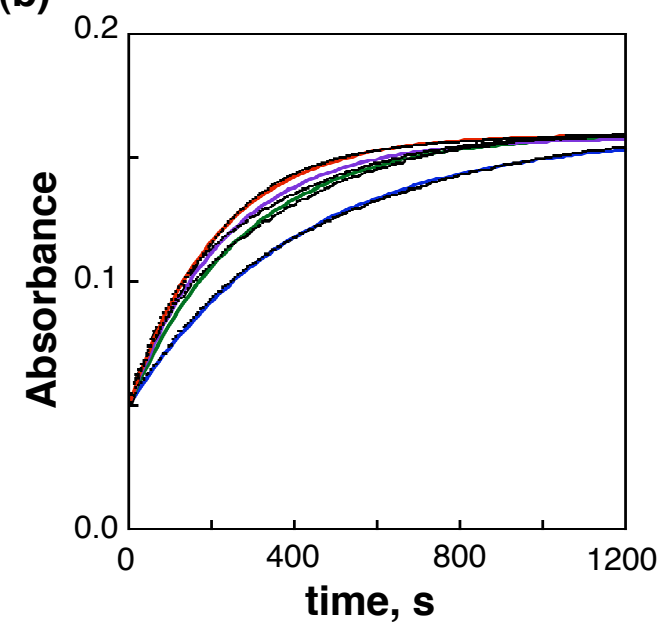

(c)

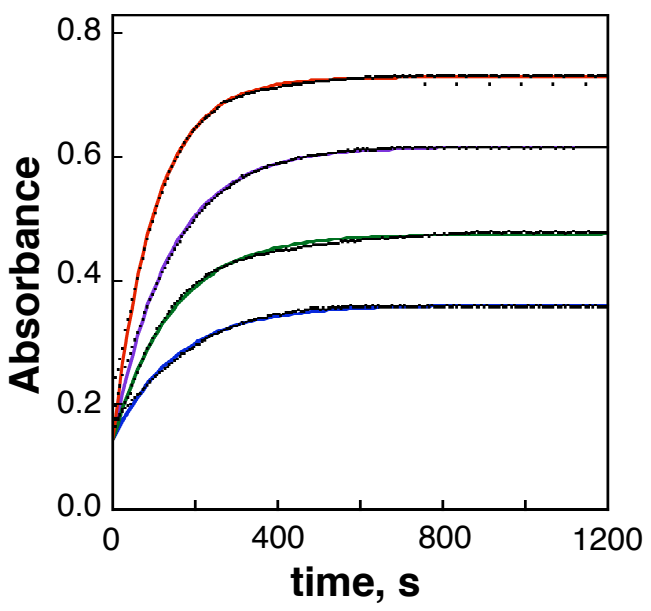

Fig. S13 Time courses of the oxidation reactions of 1-propanol with $0.025 \mathrm{M}$ (blue), $0.05 \mathrm{M}$ (green), $0.10 \mathrm{M}$ (purple), $0.15 \mathrm{M}$ (red) in the presence of complexes a) 4, b) 5 and c) 6 as oxidants $(0.5 \mathrm{mM})$ at $301 \mathrm{~K}$. 

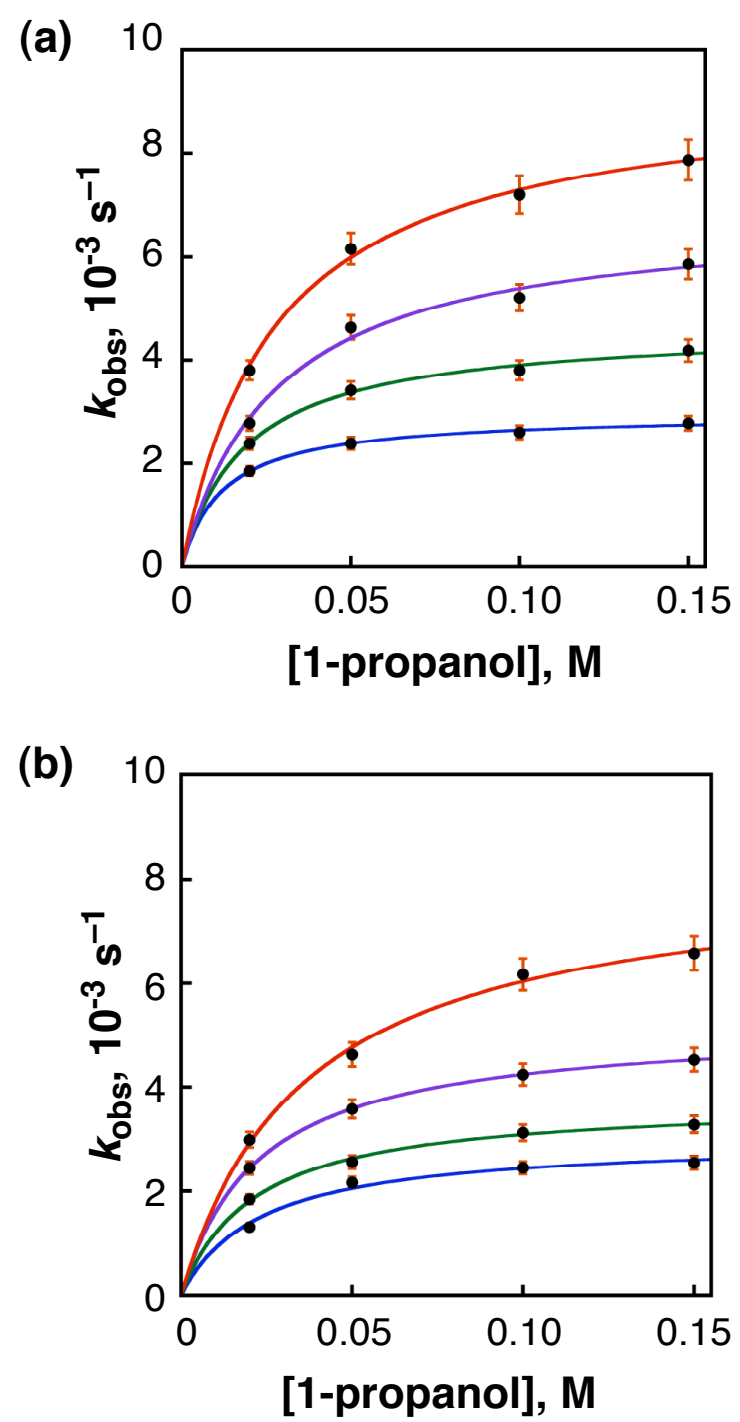

Fig. S14 Pseudo first-order kinetic analysis for oxidation of 1-propanol with complexes (a) 4, and (b) 5 as oxidants $(0.5 \mathrm{mM})$ in B.-R. buffer (pH 1.8) at $308 \mathrm{~K}$ (red), $301 \mathrm{~K}$ (purple), $288 \mathrm{~K}$ (green), $280 \mathrm{~K}$ (blue). 
(a)

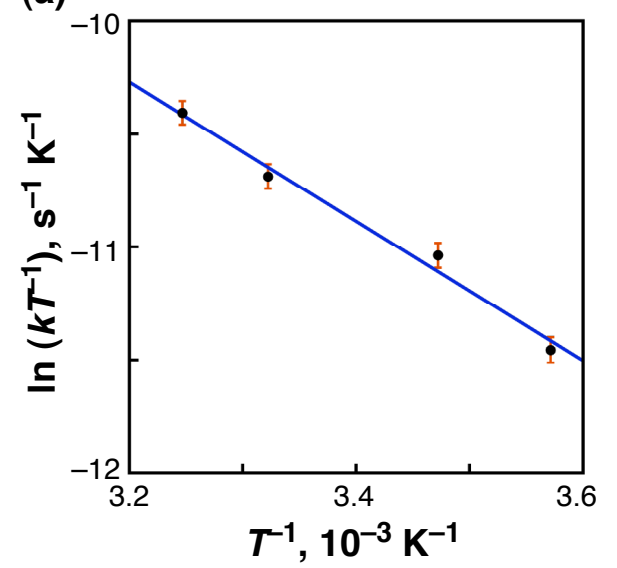

(b)

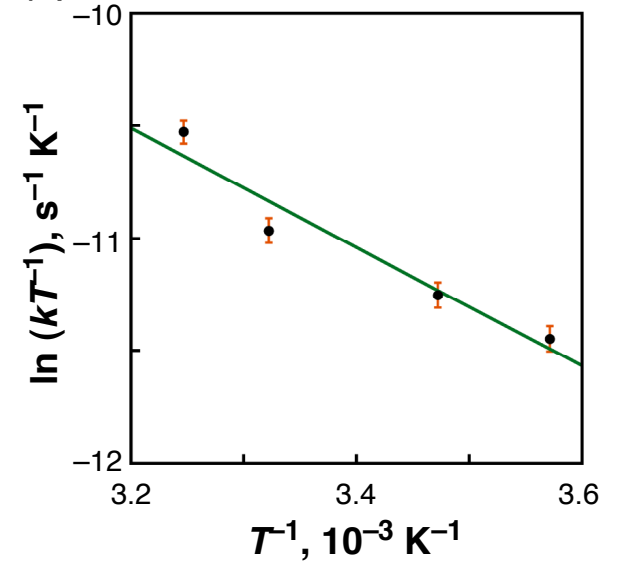

(c)

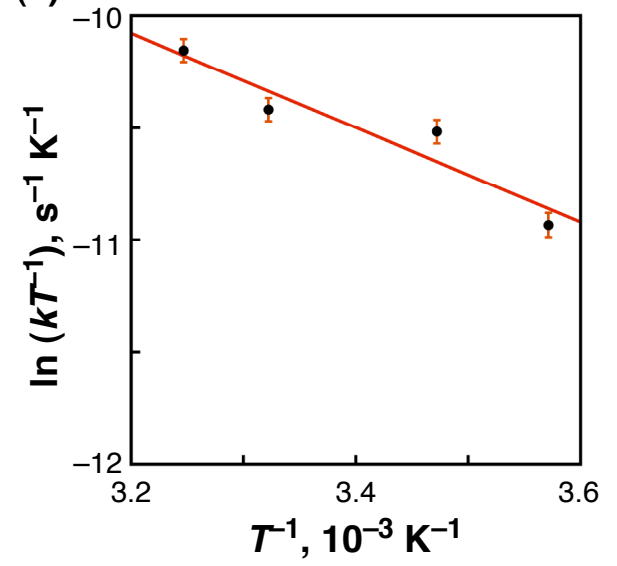

(d)

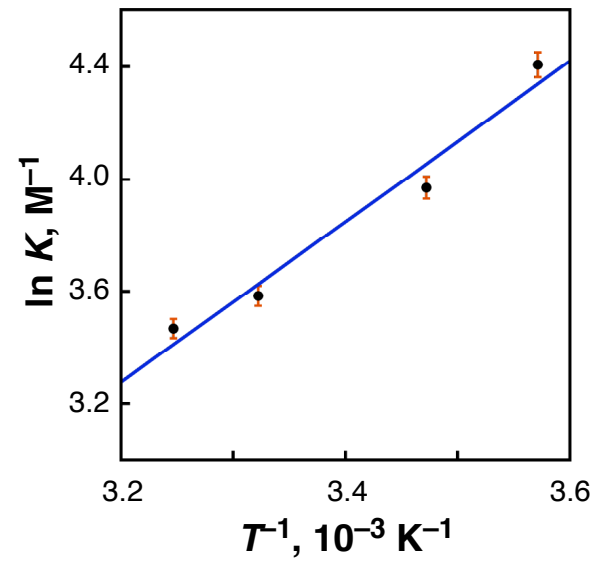

(e)

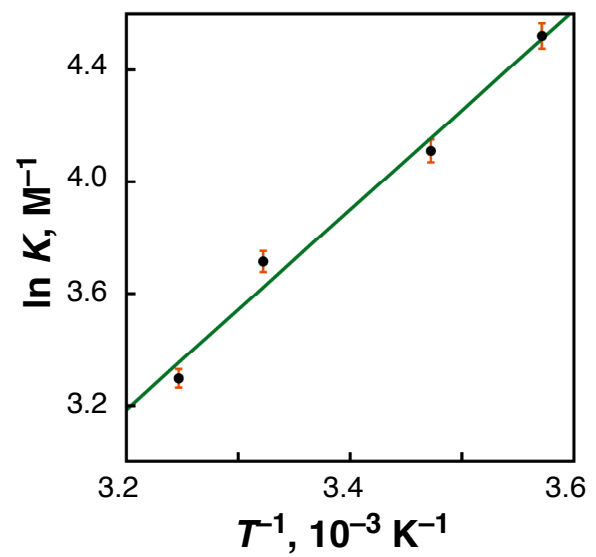

(f)

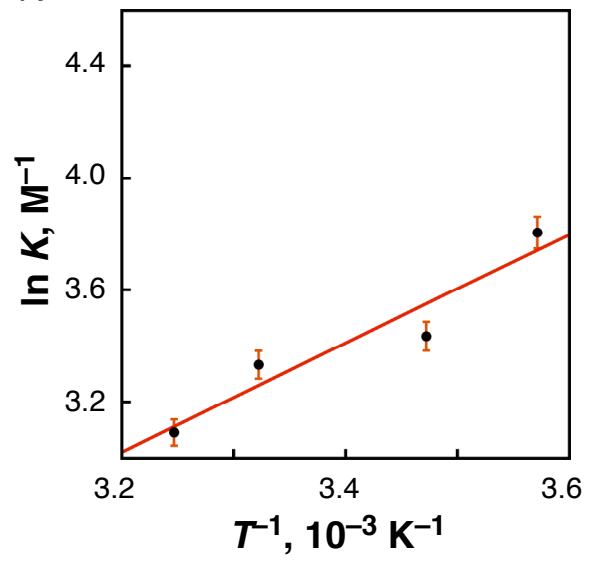

Fig. S15 Eyring (a, b and c) and van't Hoff plots (d, e and f) for oxidation of 1-propanol with complexes 4 (a, d), 5 (b, e) and $\mathbf{6}(\mathrm{c}, \mathrm{f})$ as oxidants. 


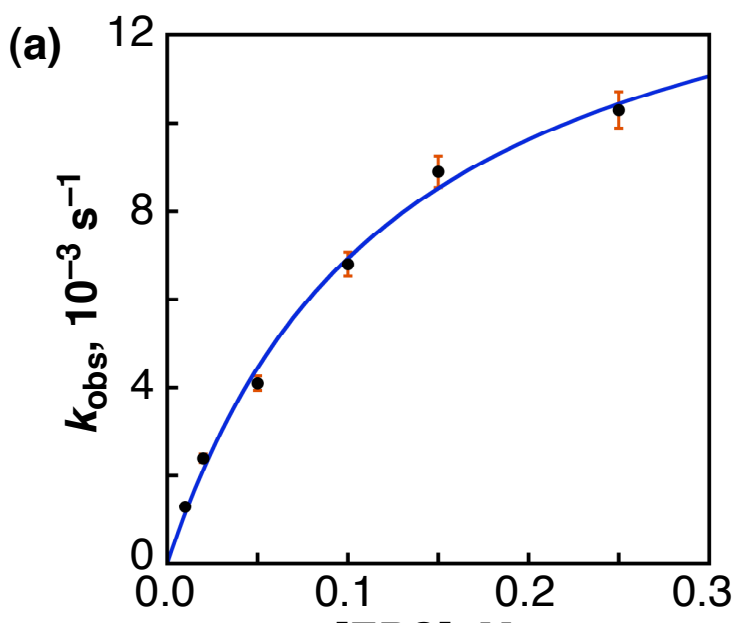

[EBS], M
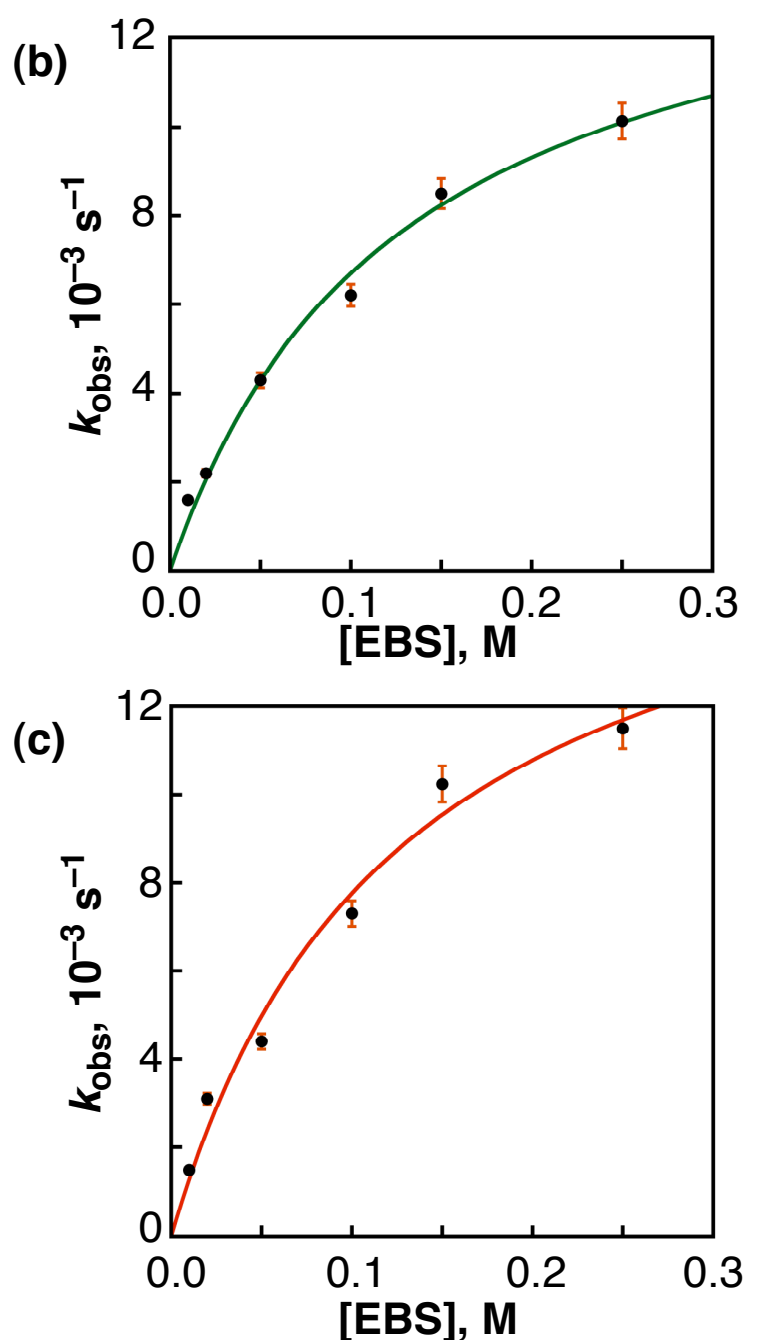

Fig. S16 Pseudo-first-order kinetic analysis for oxidation of sodium 4-ethylbenzenesulphonate with complexes (a) 4, (b) 5 and (c) 6 as oxidants $(0.5 \mathrm{mM})$ in B.-R. buffer (pH $1.8)$ at $295 \mathrm{~K}$. 

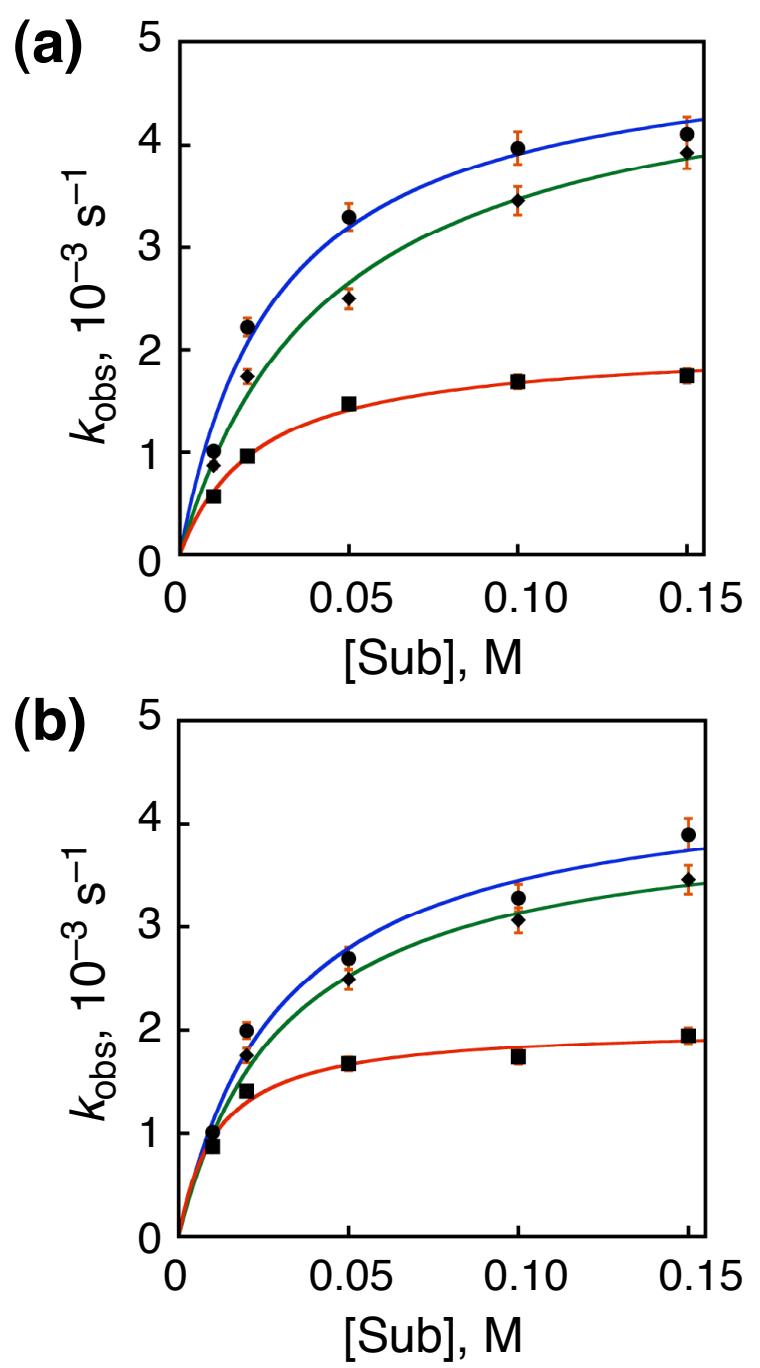

Fig. S17. Pseudo-first-order kinetic analysis for oxidation reactions of $\mathrm{CH}_{3} \mathrm{OH}$ (blue line), $\mathrm{CD}_{3} \mathrm{OH}$ (red line) and $\mathrm{CH}_{3} \mathrm{OD}$ (green line) with complexes (a) 4 and (b) 5 as oxidants at 297 $\mathrm{K}$. $\mathrm{CH}_{3} \mathrm{OH}$ and the deuterated derivatives $\left(\mathrm{CD}_{3} \mathrm{OH}\right.$ and $\left.\mathrm{CH}_{3} \mathrm{OD}\right)$ were used as substrates. 